\title{
TRADISI MEGENGAN DALAM MENYAMBUT RAMADHAN
}

Living Qur'an Sebagai Kearifan Lokal Menyemai Islam di Jawa

\author{
Ali Ridho \\ Mahasiswa Magister Komunikasi dan Penyiaran Islam \\ Fakultas Dakwah dan Komunikasi \\ Universitas Islam Negeri (UIN) Sunan Kalijaga Yogyakarta \\ E-mail: ridhoali975@gmail.com
}

\begin{abstract}
Abstrak
Seiring perkembangan zaman yang terus mengalami evolusi, kajian alQur'an mengalami perkembangan dalam konteks wilayah kajiannya. Dari yang awalnya berupa kajian teks menjadi kajian sosial-budaya, yang menjadikan masyarakat agama sebagai objek kajian utamanya yang sering disebut sebagai kajian Living Qur'an. Salah satu fenomena Living Qur'an adalah tradisi Megengan dalam menyambut datangnya bulan Ramadhan di masyarakat Jawa. Tradisi Megengan ini dikategorikan sebagai fenomena Living Qur'an karena memenuhi lima indikator. Pertama, tujuan utama dari tradisi Megengan adalah untuk meyiarkan ajaran Islam ke dalam masyarakat, khususnya adalah masyarakat Nusantara (Jawa). Kedua, bentuk daripada doa kepada para leluhur yang telah berpulang kehadirat Allah Azza wa Jalla. Ketiga, wujud pemberian sedekah berupa makanan kepada tetangga. Keempat, meneguhkan Al-Akhwah dan Al-shilah al-Rahim (Persaudaraan dan Kasih Sayang). Tradisi Megengan menjadi bukti sejarah yang hingga terus menancap kuat di dalam amsyarakat Islam, bahwa Islam di Nusantara (Jawa) proses menyebarkannya identik dengan menggunakan pendekatan persuasif-cultural, yang hasilnya adalah Islam yang mendamaikan dan penuh dengan khazanah tradisi dan kebudayaan.
\end{abstract}

Kata Kunci: Tradisi, Megengan, Islamisasi, Living Qur'an.

\section{A. PENDAHULUAN}

Islam sebagai agama yang rahmatan lil alamin dipahami oleh para wali ${ }^{1}$ sebagai penyebar Islam di tanah Jawa, sehingga dalam menyebarkan ajaran agama Islam mereka melakukannya dengan cara yang bijaksana dan tanpa kekerasan. Kebijakan para wali dalam menyebarkan ajaran Islam di Jawa antaranya dapat dilihat dari bagaimana mereka tidak menghancurkan tradisi yang telah ada bahkan justru tradisi yang telah ada tersebut disesuaikan dengan ajaran atau syariat Islam. Realitas tersebut di atas menjadikan tanah Jawa sebagai daerah yang sangat banyak menyimpan tradisi dengan seluruh warna-

${ }^{1}$ Wali atau Waliyullah adalah orang orang yang dikasihi Allah. Kata wali mengandung banyak arti. Bisa bermakna 'teman', 'kekasih', atau 'pengikut'. Dalam Al-Qur'an, dijumpai kata auliya Allah yang berarti 'kekasih Allah', 'orang-orang terkasih dan dicintai'. Secara umum, wali/aulia Allah adalah hamba yang sungguh-sungguh mengabdi, menaati Allah dan Rasul-Nya sehingga diistimewakan dan mendapat maqam (kedudukan/derajat) mulia di sisi-Nya. (Q.S. Yunus: 62-63) Tanah Jawa (Nusantara) konon dikenal dengan sebutan negeri sejuta wali, setelah Hadralmaut, Yaman. 
warninya dan menjaga (melestarikan)-nya secara dinamis dalam rentang waktu cukup panjang bahkan hingga sekarang. Perkembangan agama Islam di Indonesia yang berlangsung secara evolutif telah berhasil menanamkan keImanan, keIslaman, hingga keindahan akhlak yang bercumber dari matangnya Ihsan masyarakat Nusantara. Memunculkan cipta, rasa, dan karsa oleh pemeluk-pemeluknya. Sebelum kedatangan Islam, masyarakat telah memeluk agama yang berkembang secara evolutif pula, baik dari penduduk asli (yang menganut animisme, dinamisme, veteisme, dan sebagainya).

Namun, Jawa adalah masyarakat beserta sistemnya yang lebih kompleks. Dalam sumber yang berbeda, disebutkan bahwa religiositas masyarakat Jawa terdapat dalam ajaran Kapitayan. Keyakinan yang telah ada pada masa sebelum kedatangan Hindu-Budha yang merupakan agama-agama yang menjadi representasi nyata dari dua kerajaan besar kala itu, yaitu Sriwijaya dan Majapahit. Kapitayan ini lebih menyerupai ketauhidan daripada animismedinamisme seperti yang kebanyakan peneliti anggap. Penyebutan sebagai animisme-dinamisme sendiri muncul oleh karena, secara tampilan fisik, ritual yang dilakukan oleh para penganutnya tampak sebagai penyembahan terhadap benda-benda. Secara sederhana, penyembahan benda-benda itu dipahami sebagai pemujaan terhadap kekuatan benda itu sendiri (animisme-dinamisme). Sebenarnya, pada awalnya ajaran Kapitayan justru tidak menyembah benda itu sebagai kekuatan mutlak, namun lebih pada penyembahan Sang Hyang, kekuatan tertinggi. Benda-benda yang terdapat dalam ritual keagamaan, seperti pohon, batu, dan mata air adalah beberapa perwujudan saja dari kekuatan yang maha tinggi Sang Hyang tersebut.

Berbicara tentang konsep Islam vis a vis tradisi dalam disiplin antropologi ada dua konsep penting yaitu "tradisi besar" (grand tradition) dengan tradisi kecil (little tradition). Konsep ini dikenalkan oleh Jacques Duchesne Guillemin yang menyatakan bahwa akan selalu terjadi dialog antara tatanan nilai agama yang menjadi cita-cita religius dari agama dengan tata nilai budaya lokal. Pertautan dialektis yang kreatif antara nilai universal dari agama dengan budaya lokal telah menghadirkan corak ajaran Islam dalam kesatuan spiritual dengan corak budaya yang beragam (unity and diversity). ${ }^{2}$

Bila kita melihat kepada historis sejarah, Islam merupakan agama yang diturunkan kepada nabi Muhammad saw yang berdomisili di jazirah Arab. Oleh karena itu ajaran dan ritual keagamaan saat itu kental dengan budaya Arab. Cara pakaian nabi, makanan, dan perilaku masyarakat yang dipimpinnyapun merupakan ciri khas orang Arab. Kemudian masalah yang timbul adalah ketika Islam sudah menyebar keseluruh dunia, dalam artian Islam sudah meninggalkan daerah di mana Islam itu sendiri dilahirkan, yaitu Arab.

Menyemainya agama Islam di Nusantara ditandai dengan kerajaan Majapahit, yaitu sebuah kerajaan besar bercorak Hindu yang tidak berumur panjang. Kekuasaan politiknya yang efektif hanya berlangsung selama sekitar

${ }^{2}$ Syamsul Arifin dkk., Spiritualisasi dan Peradaban Masa Depan, (Yogyakarta: SIPRESS, 1996), h. 50-51. 
satu abad saja (sampai akhir abad keempat belas, tepatnya tahun 1398), atau sekitar dua abad saja sampai sisa kekuasaannya benar-benar habis menjelang akhir abad kelima belas (tepatnya tahun 1478, "sirna ilang kertaning bumi"). ${ }^{3}$ Walaupun begitu, berkat pola budayanya yang mapan, Majapahit adalah kerajaan kuno di Indonesia yang terbesar dan paling berpengaruh. Lebih-lebih jika dilihat dari segi pola budaya yang diwariskannya, Majapahit adalah kerajaan Nusantara kuno yang pengaruhnya paling nyata saat ini.

Segera menyusul runtuhnya Majapahit, pada permulaan abad kelimabelas, Islam di Jawa yang sebelumnya sudah tumbuh di kota-kota pelabuhan dan menjadi agama para pedagang, diantaranya adalah Gujarat ${ }^{4}$ yang mulai mengkonsolidasikan diri secara politik. Dibuktikan dengan batu nisan Maulana Maghribi (Malik Ibrahim), terdapat angka yang menunjukkan tahun kematiannya yaitu $1419 .{ }^{5}$ Kemudian laporan yang ditulis Cheng Ho, anggota Perutusan Tionghoa (1413 C), sekitar abad XV M di pesisir utara telah ada pemeluk Islam yang dinyatakan mereka itu berpakaian bersih, sedang yang lain yang non-muslim masih kelihatan kotor. ${ }^{6}$

Dalam mewarnai suatu kebudayaan dengan nafas Islam harus diperhatikan beberapa hal: kebudayaan tersebut tidak harus sepenuhnya bercorak Islam pada waktu itu juga. Dalam artian harus melalui proses yang sangat panjang dan membutuhkan waktu yang sangat lama. Kebudayaan yang telah diberi nafas Islam masih sesuai dengan tujuan Islam, yaitu sebagai agama yang rahmatan lil alamin. Islam adalah agama yang berkarakteristik universal, dengan pandangan hidup (weltanchaung) mengenai persamaan, keadilan, takaful, kebebasan, dan kehormatan serta memiliki konsep teosentrisme yang humanistic sebagai nilai inti (core value) dari seluruh ajaran Islam, dan karenanya menjadi tema peradaban Islam. Contoh yang paling urgen tentang akulturasi budaya dengan Islam adalah ketika Budaya Jawa pada zaman HinduBudha bersinggungan dengan penyebaran Islam pada masa itu. ${ }^{7}$

${ }^{3}$ Aboebakar, Sejarah Hidup K.H.A Wahid Hasyim dan Karangan Tersiar, (Jakarta: Panitia Buku Peringatan Alm. KH A. Wahdi Hasyim, 1957), h. 25, Sejarah al-Qur'an (Jakarta: Sinar Pujangga, cet. III, 1952), H. 279, dan H. J. Van den Berg, Dari Panggung Peristiwa Sejarah Dunia, Jilid I, terj. Koeskamp, I. P. Simandjoentak, (Jakarta: J. B Walters, 1951, h. 382

${ }^{4}$ K. P. Kaya, Dakkhin Bharate Muslim Missionai, terj. Abul Quasem Bhuiyan (Faridpur: Islamic Cultural Center, 1980), h. 1-3, S. M. Husen Nainar, Islam di India dan Hubunganhubungannya dengan Indonesia, (Jakarta: Information Service of India, 1956), h. 9-22, dan Azyumardi Azra, Jaringan Ulama Timur Tengah dan Kepulauan Nusantara Abad XVII dan XVIII, (Bandung: Mizan, 1994), h. 24-31, mecatat adanya perbedaan pendapat mengenai dari mana asal kedatangan Islam ke Indonesia, diantaranya adalah dari Anak Benua India, Pantai Gujarat, Bengal, Pantai Coromandel Malabar, dan langsung dari Arab.

${ }^{5}$ Mukti Ali, The Spread of Islam in Indonesia, (Yogyakarta: Yasayasan "Nida", 1970, h. 11-12, dan Thomas Arnold, The Preaching of Islam: (Lahore: Sh. Mohammad Ashraf, Kashmiri Bazar, cet. Ii, 1965), h. 383

${ }^{6}$ Hamka, Sejarah Umat Islam, (Jakarta: Nusantara, 1961, h. 684, R. Soekmono, Pengantar Sejarah Kebudayaan Indonesia III, (Yogyakarta: Yayasan Kanisius, 1973), h. 46, dan TK. Islamil Jakub, Sejarah Islam di Indonesia, (Jakarta: Wijaya, t. th.), h. 24

7 Salman Faris, Islam dan Budaya Lokal (Studi Atas Tradisi Keislaman Masyarakat Jawa), Jurnal Thaqafiyyat, Vol. 15, No. 1, Juni, (Jakarta: STAI Az-Ziyadah, 2014), h. 76

VOLUME 1, NO. 2 Juli - Desember 2019 
Jika melihat fakta historis di atas, Nusantara telah lama diwarnai oleh kebudayaan Hindu-Budha, maka Islam dalam proses penyebarannya melahirkan suatu sikap kearifan terhadap tradisi dan budaya yang telah ada dengan melakukan dekonstruksi terhadap nilai-nilai yang terkandung di dalamnya, tanpa harus menghilangkan wujud dari tradisi-budaya tersebut. Diantaranya bisa dipotret pada momen penyambutan datangnya bulan Romadlan hingga awal bulan Syawal adalah meriahnya berbagai tradisi yang menjadi ciri khas dari masing-masing daerah di Indonesia. Yakni, tradisi megengan dan saling memohon maaf di awal Ramadhan. Ada tradisi weweh maleman seperti pada akhir-akhir bulan Ramadhan. Menjelang Syawal hingga setelah shalat 'Idul Fitri ada lagi tradisi nyadran atau nyekar (berziarah kubur). Kupatan pada tanggal tujuh Syawal menjadi penutup rangkaian tradisi-tradisi itu.

Fenomena-fenomena tersebut menarik untuk diteliti, khususnya fenomena yang berupa pola-pola perilaku masyarakat Islam yang muncul dari pemahaman mereka terhadap al-Qur'an sebagai salah satu pedoman induk umat Islam. Hal ini juga sejalan dengan perkembangan studi al-Qur'an yang juga merambah pada wilayah penghayatan dan pengamalan al-Qur'an dalam ritus kehidupan. Kajian terhadap fenomena ini belakangan dikenal dengan istilah kajian living Qur'an. Dengan kata lain, living qur'an yang sebenarnya bermula dari fenomena Qur'an in Everyday Life, yakni makna dan fungsi alQur'ean yang riil dipahami dan dialami masyarakat muslim. ${ }^{8}$

Arah dan tawaran baru tersebut setidaknya berkaitan dengan realitas masyarakat yang dihubungkan dengan al-Qur'an. Banyak tawaran untuk mengkaji realitas sosial, salah satunya oleh Sahiron Syamsuddin, yang menawarkan dua tawaran dalam mengkaji al-Qur'an dalam tataran realitas, yaitu menekankan atas pehamanan teks, sejak Nabi Muhammad saw. hingga sekarang al-Qur'an dipahami dan ditafsirkan oleh umat Islam, baik secara keseluruhan maupun hanya bagian-bagian tertentu dari al-Qur'an, dan baik secara mushaf maupun secara tematik. Selain itu, juga melihat atau memotret respons masyarakat atas pemahaman dan penafsiran atas Al-Qur'an. ${ }^{9}$ Dengan demikian, penulis ingin mengangkat tema yang berkaitan erat dengan AlQur'an pada tataran realitas masyarakat, yang menjadi kajian konsens Living Qur'an, khususnya yang berkaitan dengan tradisi megengan dalam menyambut Ramadhan.

${ }^{8}$ Living Qur'an tersebut sebenarnya dimulai dari gagasan kecil pada tahun 2005. Pada masa tersebut, Forum Komunikasi Mahasiswa Tafsir Hadis Indonesia (FKMTHI) mengadakan kongres yang didahului dengan seminar berjudul "Living Qur'an: Al-Quran dalam Kehidupan Sehari-hari" dan salah satu dosen yang konsens memberikan wacana dan mendukung ialah Muhammad Mansyur dan Ahmad Rafiq. Lihat Hamam Faizin, "Al-Qur'an Sebagai Fenomena yang Hidup (Kajian atas Pemikiran Para Sarjana Al-Qur'an)”, dalam International Seminar and Quranic Confrence II, Yogyakarta, 24 Februari 2012, h. 1

9 Sahiron Syamsuddin, "Ranah-ranah dalam Penelitian Al-Qur'an dan Hadis", Kata Pengantar, dalam Metodologi Penelitian Living Qur'an dan Hadis (Yogyakarta: Teras, 2007), h. $18-24$ 


\section{METODE PENELITIAN}

Penelitian ini merupakan penelitian kepustakaan (library research). Sumber data yang digunakan bersumber dari data-data yang berupa bahanbahan tertulis yang dipublikasikan dalam bentuk jurnal, artikel, disertasi, tesis, kitab, majalah, surat kabar hingga halaman website yang dianggap mendukung dan representatif. Adapun langkah-langkah yang diambil dalam pengumpulan data adalah mengumpulkan keseluruhan data tentang living Qur'an dan tradisi megengan dalam menyambut datang bulan Ramadhan, baik dari perpustakaan induk UIN Sunan Kalijaga dan perpustakaan daerah, Yogykarta. Sedangkan analisis data pada penelitian ini digunakan metode induktif. ${ }^{10}$ Yaitu pola pikir yang berangkat dari nilai-nilai khusus yang bersifat partikular untuk selanjutnya diturunkan pada sejumlah kasus umum. ${ }^{11}$ Untuk itulah dilihat objek-objek living Qur'an dari teksnya yang asli kemudian dilihat perkembangannya di masyarakat dengan melihat metodologi yang sesuai dengan masing-masing objek kajiannya.

Sementar itu, pendekatan yang digunakan dalam penelitian ini adalah historis filosofis, ${ }^{12}$ yakni upaya untuk menelisik persoalan ini dari kacamata historis terutama ketika menelusuri rekaman jejak dilaksanakannya tradisi megengan dalam menyambut datangnya bulan Ramadhan di bumi Nusantara, khusunya pulau Jawa. Selain itu, juga dipakai pendekatan yang berkaitan dengan fenomena sosial-budaya, seperti fenomenologi dan akulturasi. Pendekatan fenomenologi, menurut G. Van der Leew, bertugas untuk mencari atau mengamati fenomena sebagaimana yang tampak. Dalam hal ini ada tiga prinsip yang tercakup didalamnya: (1) sesuatu itu berwujud; (2) sesuatu itu tampak; (3) karena sesuatu itu tampak dengan tepat maka ia merupakan fenomena. Penampakan itu menunjukkan kesamaan antara yang tampak dengan yang diterima oleh si pengamat, tanpa melakukan modifikasi. ${ }^{13}$ Sementara pendekatan akulturasi dipakai untuk mengetahui proses dan hasil interaksi antara ajaran-ajaran yang ada dalam hadis dengan sistem kepercayaan atau budaya lokal dalam suatu masyarakat. ${ }^{14}$

\section{PEMBAHASAN}

\section{A. Terminologis Tradisi}

Tradisi merupakan nilai-nilai dan atau aturan perilaku yang diwariskan dari generasi ke generasi. Dengan kata lain tradisi adalah nilai yang diberikan pada suatu kebiasaan atau adat istiadat. Namun secara lebih lengkap, tradisi dimaknakan keseluruhan benda material dan gagasan yang berasal dari masa

$5-6$.

${ }^{10}$ Noeng Muhadjir, Metodologi Penelitian Kualitatif, (Yogyakarta: Rake Sarasin, 1996), h.

${ }^{11}$ Mundziri, Logika, (Jakarta: PT Raja Grafindo Persada, 1996), h. 12.

${ }^{12}$ Soerjono Soekanto, Pengantar Penelitian Hukum (Jakarta: UI Press, 1986), h. 50-51.

13 Moh. Natsir Mahmud, "Studi Al-Qur"ean dengan Pendekatan Historisisme dan Fenomenologi Evaluasi Terhadap Pandangan Barat tentang Al-Qurean" Disertasi, (Yogyakarta: Program Pasca Sarjana IAIN Sunan Kalijaga Yogyakarta, 1992, tidak diterbitkan), h. 90.

14 Heddy Shri Ahimsa-Putra, "Menafsir ,al-Qur"an yang Hidup", Memaknai alQur"anisasi Kehidupan: Perspektif Antropologi Budaya”, Makalah Seminar "Living Qur"an: AlQur"ean sebagai Fenomena Sosial Budaya”, Yogyakarta, 13-15 Maret 2005, h. 9. 
lalu, namun wujudnya masih dirasakan hingga saat ini. ${ }^{15}$ Tanpa adanya tradisi, pergaulan bersama akan menjadi kacau, dan hidup manusia akan menjadi biadab. Namun demikian, jika tradisi mulai bersifat absolut, nilainya sebagai penerang akan padam. Jika tradisi mulai absolute, bukan sebagai penerang, akan menjadi tembok yang menghalangi menuju kemajuan. Maka dari itu, tradisi yang telah lama kita terima sudah selayaknya memerlukan perenunganperenungan kembali dengan menyesuaikan akan perubahan zaman. ${ }^{16}$

A.R. Idham Kholid dengan mengutip pendapat Abdullah Ali mengatakan, bahwa tradisi sebagai suatu adat istiadat atau kebiasaan yang seringkali dianggap irasional, pada prakteknya selalu melahirkan pro dan kontra, antara kelompok masyarakat yang mendukung dan yang menentang. Bahkan tidak jarang aktivitas tradisional selalu dianggap menghambat upaya pembangunan yang mengarah pada perubahan dan kemajuan suatu masyarakat modern. ${ }^{17}$

Sementara itu menurut Hasan Hanafi, tradisi diartikan sebagai segala bentuk warisan masa lampau, hingga berjalan sampai menuju zaman saat ini dan menjadi bagian dari kebudayaan yang sekarang berlaku. Berarti bagi pandangan Hasan, bahwa tradisi tidak hanya dalam bentuk peninggalan sejarah, tetapi juga sekaligus merupakan persoalan zaman ini dengan berbagai tingkatan-tingkatannya. ${ }^{18}$ Tradisi kemudian dalam perkembangannya, mulai persepsikan dengan kata-kata adat yang dalam pandangan masyarakat umum kemudian dipahami sebagai sebuah konsep yang sama. Dalam hal ini sebenarnya berasal dari bahasa arab adat (bentuk jamak dari 'adah) yang berarti kebiasaan dan dianggap bermakna sama dengan 'urf, sesuatu yang dikenal atau diterima secara global. ${ }^{19}$ Tradisi terus mengalami perubahanperubahan dalam bentuk yang besar ataupun kecil. Tradisi menjadi suatu objek yang wariskan dari generasi hulu menuju generasi hilir bukan secara gradual, namun melalui telaah ulang yang bertujuan mendekonstruksi yang selanjutnya ditanamkan kepada masyarakat. Sehingga khazanah pemikiran dalam memahami menimbulkan keberagaman sesuai dengan konteks cirri kekhasan masing-masing daerah. ${ }^{20}$ Pada akhirnya tradisi yang telah menjadi akar budaya yang kuat di dalam suatu daerah tertentu akan menjadi rujukan masyarakat untuk berakhlak dan berbudipekerti, meskipun di dalam diri mereka sebelumnya telah memiliki format berperilaku dengan sendirinya. ${ }^{21}$

${ }^{15}$ Nanang Martono, Sosisologi Perubahan Sosial: Perspektif Klasik, Modern, Postmodern, dan Poskolonial, (Jakarta: Rajagrafindo Persada, 2012), h. 315

${ }^{16}$ Mardimin Johanes, Jangan Tangisi Tradisi, (Yogyakarta: Kanisius, 1994), h. 12-13

17 A.R. Idham, Cholid, Wali Songo: Eksistensi Dan Perannya Dalam Islamisasi dan Implikasinya Terhadap Munculnya Tradisi-Tradisi di Tanah Jawa, Jurnal Tamaddun, Vol 4, Edisi 1 Januari-Juni, (Cirebon: IAIN Syekh Nurjati, 2016), h. 26

${ }^{18}$ Muhammad Nur Hakim, Islam Tradisional dan Reformasi Pragmatisme (Agama Dalam Pemikiran Hasan Hanafi), (Malang: Bayu Media Publishing, 2003), h. 29

${ }^{19}$ Muhaimin AG, Islam Dalam Bingkai Budaya Lokal: Potret Dari Cirebon, terjemah oleh Suganda, (Ciputat: Logos Wacana Ilmu, 2001), h. 11

${ }^{20}$ Ahmad Khalil, Islam Jawa Sufisme Dalam Etika dan Tradisi Jawa, (Malang: UIN Press, 2008), h. 1-3

${ }^{21}$ Bey Arifin, Hidup Setelah Mati, (Jakarta: Dunia Pustaka, 1984), h. 80 


\section{B. Mengenal Tradisi Megengan}

Transmisi Islam yang dipelopori oleh para Walisongo memang menunjukkan jalan dan alternatif baru yang di design sengaja tidak mengusik tradisi dan kebiasaan lokal. Malah, Islam yang didesiminasikan adalah berbentuk Islam yang mudah ditangkap oleh orang awam karena pendekatan Walisongo yang realistis, tidak njlimet dan menyatu dengan kehidupan masyarakat. Ini sejalan dengan konsep modern: model of development fron within. ${ }^{22}$ Dampaknya, luar biasa. Islamisasi ini berjalan dengan sukses besar dan masyarakat Jawa pun berbondong-bondong masuk Islam.

Dampak positifnya, cara ini telah membuahkan Islamisasi besar-besaran di Jawa tanpa gejolak. Ini karena Walisongo tidak menghapus tradisi dan kepercayaan lama secara radikal dan frontal, yang mereka hilangkan hanyalah yang jelas-jelas bertentangan dengan ajaran Islam. Tradisi yang terang berseberangan dengan Islam, oleh para Walisongo, diganti dengan unsurunsur ajaran Islam. Meminjam bahasa Purwadi, terjadi akulturasi dan sinkritisasi antara tradisi dan kepercayaan lokal di satu pihak dengan ajaran dan kebudayaan Islam di pihak yang lain. Dalam akulturasi ini, Islam memberikan pengaruh kepada tradisi dan kepercayaan lokal, dan sebaliknya, tradisi lokal memberikan pengaruh pada pelaksanaan ajaran Islam. ${ }^{23}$

Diantara bentuk tradisi yang hingga saat ini masih menjadi corak keberagamaan masyarakat tanah Jawa yang setiap datangnya bulan Ramadhan nampak dilakukan adalah tradisi Megengan. ${ }^{24}$ Dalam budaya Jawa, Megengan merupakan budaya yang dikenal dengan upacara yang disakralkan secara tradisi. Dalam Islam terdapat delapan bulan yang dinyatakan sebagai bulan suci, yaitu bulan Muharram (Suro), Shafar (Sapar), Rabi'ul Awwal (Mulud), Rajab (Rejeb), Sya'ban (Ruwah), Ramadhan (Poso), Dzulqa'dah (Selo), dan Dzulhijjah (Besar). Pada bulan-bulan tersebut umat Islam Indonesia (Jawa) melakukan banyak ritual atau perayaan untuk memperingatinya, dan memang dalam delapan bulan tersebut mempunyai arti penting sehingga harus diperingati. Melalui peringatan atau perayaan itu keterkaitan dengan identitas sebagai Muslim diekspresikan melalui simbol-simbol tertentu. Pemaknaan filosofis bulan-bulan tersebut, lebih mudah apabila digunakan pendekatan sejarah Islam daripada kitab suci (al-Qur'an) dan hadist sebagai rujukan utama pengambilan hukum Islam selain daripada ijma', qiyas, dan lain sebagainya. Pola umum peringatan banyak dengan kombinasi multi ritual, seperti berpuasa, berdoa, sholat sunnah, bersholawat, membaca Al-Qur'an, membaca riwayat tokoh muslim atau mauizhah al-hasanah menyangkut kemuliaan bulan-bulan tersebut, menyedahkan makanan atau benda-benda lain sebagai symbol perayaannya. ${ }^{25}$

Tradisi megengan menjadi suatu ritual langka dalam perkembangan Islam di masa modern sekarang, karena di era modern perubahan dan

${ }^{22}$ Purwadi, Sejarah Sunan Kalijaga, (Yogyakarta: Persada, 2003), h. 51-52

${ }^{23}$ Purwadi, Sejarah Sunan Kalijaga, h. 53

${ }^{24}$ Muntoha, Pemikiran dan Peradaban Islam, Yogyakarta: UII Press, 1998), cet. I, h. 7

${ }^{25}$ Muhaimin, Islam dalam Bingkai Budaya Lokal Potret dari Cirebon, h. 173

VOLUME 1, NO. 2 Juli - Desember 2019 
perkembangan ilmu pengetahuan semakin maju, tetapi upacara atau tradisi megengan masih di pegang teguh dan masih tetap berlangsung. Jika melihat sistematisnya serangan yang dilakukan oleh Islam corak Arab-Timur Tengah (baca: Saudi Arabia) terhadap penganut Islam di Indonesia yang melakukan ritual keagamaan semacam megengan, selametan, dengan argument bahwa praktik tersebut yang tidak diajarkan oleh Islam. Padahal tradisi seperti megengan, di dalamnya merupakan kegiatan perkumpulan antara umat muslim dengan memanjatkan doa kepada Allah, dengan narsis dianggap sebagai bid'ah dengan dasar pemikiran bahwa dalam ajaran Islam tidak terdapat megengan, tahlilan, sepasaran, tingkepan dan lainnya. Hal ini pada dasarnya merupakan pengaruh dari gerakan kaum puritan seperti yang pernah menjadi permasalahan umat muslim setelah kemenangan Ibn Sa'ud di Semenanjung Arab. Pasca tahun 1924, jatuhnya Hijaz (sekarang Mekah) dan sekitarnya ke tangan Ibn Sa'ud, kebijakan untuk memberantas praktik yang tidak sesuai dengan pemikirannya mengenai Islam diterapkan di Arab, di samping juga memberangus tempat-tempat ziarah dan tapak tilas Nabi. Bukan hanya itu, kebebasan untuk bermazhab pun dilarang, dengan dasar bahwa Islam tidak mengenal mazhab. Di sini persoalan yang muncul tidak sederhana. Hal tersebut karena Mekkah adalah tujuan utama umat Islam di dunia untuk melaksanakan ziarah haji. Hingga pada tahun 1928, dibentuk NU, dan mengirimkan delegasinya ke Arab untuk menemui Ibn Sa'ud dan meminta kemerdekaan bermazhab (Hanafi, Maliki, Syafi'i dan Hanbali) dan dilakukannya giliran antara imam-imam salat Jumat di Masjidil Haram. ${ }^{26}$

\section{Tradisi Megengan Sebagai Fenomena Living Qur'an}

Muhammad Mansyur, berpendapat bahwa pengertian The Living Qur'an sebenarnya bermula dari fenomena Qur'an in Everyday Life, yang tidak lain adalah "makna dan fungsi al-Qur'an yang riil dipahami dan dialami masyarakat Muslim." 27 Maksud penulis di sini sejauh saya bisa memahaminya adalah "praktik memfungsikan al-Qur'an dalam kehidupan praksis, di luar kondisi tekstualnya”. Pemfungsian al-Qur'an seperti itu muncul karena adanya "praktek pemaknaan al-Qur'an yang tidak mengacu pada pemahaman atas pesan tekstualnya, tetapi berlandaskan anggapan adanya "fadhilah" atau kebermanfaatan dari unit-unit tertentu teks al-Qur'an, bagi kepentingan praksis kehidupan keseharian umat.

Dari hasil pengamatan penulis, bahasan ini dibatasi pada beberapa fenomena yang dipandang sebagai living Qur'an. Variabel atau unsur yang menentukan sesuatu sebagai fenomena living Qur'an adalah bahwa fenomena tersebut berhubungan atau bersumber, baik langsung maupun tidak langsung, al-Qur'an al-Karim. Tradisi Megengan bisa dipandang sebagai fenomena living Qur'an karena empat hal. Pertama, tujuan utama awal dari Tradisi

${ }^{26}$ Andree Feillard, NU vis-a-vis Negara, (Yogyakarta: LKiS, 1999), edisi terjemah, h. 12

${ }^{27}$ Muhammad Mansyur, Metodologi Penelitian Living Qur'an dan Hadis, (Yogyakarta: TH. Press,

2007), h. 5

VOLUME 1, NO. 2 Juli - Desember 2019 
Megengan adalah untuk meyiarkan ajaran Islam ke dalam masyarakat setelah masyarakat mulai mengenal Islam. Kedua, sebagai ungkapan rasa syukur kepada Allah Swt., sebagai atas diberikannya berbagai macam bentuk nikmat. Ketiga, bentuk daripada doa kepada para leluhur yang telah berpulang kehadirat Allah Azza wa Jalla. Keempat, wujud pemberian sedekah berupa makanan kepada tetangga. Kelima, meneguhkan Al-Akhwah dan Al-shilah alRahim (Persaudaraan dan Kasih Sayang)

\section{Tradisi Megengan Sebagai Sarana Menyiarkan Islam}

Dalam konteks dakwah Islam, tradisi semacam ini bisa dijadikan sebagai media pengenalan dan penyebaran agama Islam. Dengan tujuan dakwah itulah, maka kita bisa memahami dimunculkannya berbagai macam tafsir otak-atikgatuk dalam rona-rona tradisi tersebut. Ini bukanlah tafsir baku, namun merupakan hasil kreativitas untuk menyampaikan pesan-pesan dakwah melalui pelaksaan tradisi, yakni megengan. Perubahan yang diadakan dalam penyebaran agama Islam ini tidak memaksakan perubahan yang drastis, namun perlahan-lahan dan justru cenderung mempertahankan bentuk. Oleh Sunan Bonang, misalnya, salah satu dari Walisongo, upacara Panca Makara ini diubah substansinya namun tetap pada bentuknya. Yaitu terdapat perkumpulan orang yang duduk melingkar, terdapat makanan sebagai tanda syukur kepada Allah, dan mengganti ritual persetubuhan, pertapaan, dan ekstase dengan berdoa pada Allah. "Ma Lima" sebagai istilah yang digunakan dalam penyebutan syarat-syarat Panca Makara pun diubah maknanya sebagai lima larangan "ma", yaitu madat (minuman keras), madon (bermain perempuan), maling (mencuri), main (judi), dan maksiat (perbuatan buruk). ${ }^{28}$ Hal tersebut lebih mudah dipahami oleh kalangan masyarakat awam, sekaligus melakukan pemaknaan ulang dalam kaitannya mencegah terjadinya Ma Lima dalam ajaran kuno terjadi kembali. Dengan model perubahan semacam ini, masyarakat tidak terlalu kaget dan terlalu banyak beradaptasi. Dipengaruhi dengan cara pandang tasawuf pula, yang tidak mementingkan bentuk fisik, perubahan-perubahan yang diupayakan oleh Walisongo dalam masyarakat Jawa adalah perubahan pemikiran dan keyakinan, bukan pada perubahan adat dan tradisi yang memang tidak diharuskan dalam Islam, tanpa terkecuali tradisi Megengan. Sekiranya para wali menggunakan metode serampangan dan mengedepankan emosional dalam memahamkan Islam pada masyarakat Nusantara kala itu, tentu akan memunculkan sikap apriori dan penolakan dari mereka. Sehingga mencoreng esensi pelaksanaan dakwah Islam itu sendiri, sebagaimana yang difirmankan oleh Allah Swt:

${ }^{28}$ Sayfa Aulia Achidsti, Strategi Penyebaran Tradisi Islam Pada Masyarakat Jawa, Jurnal Kebudayaan Islam, Vol. 10, No. 2, Juli-Desember, (Yogyakarta: Universitas Gadjah Mada (UGM), 2012), h. 207 


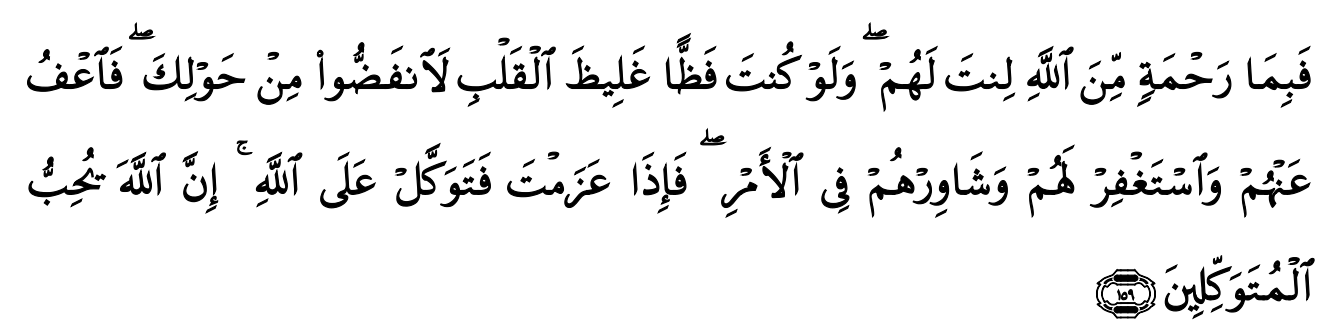

Artinya: "Maka disebabkan rahmat dari Allah-lah kamu Berlaku lemah lembut terhadap mereka. Sekiranya kamu bersikap keras lagi berhati kasar, tentulah mereka menjauhkan diri dari sekelilingmu. karena itu ma'afkanlah mereka, mohonkanlah ampun bagi mereka, dan bermusyawaratlah dengan mereka dalam urusan itu. kemudian apabila kamu telah membulatkan tekad, Maka bertawakkallah kepada Allah. Sesungguhnya Allah menyukai orangorang yang bertawakkal kepada-Nya.” (QS. Ali 'Imran: 159)

\section{Tradisi Megengan Sebagai Wujud Do'a Kepada Leluhur}

Di dalam tradisi megengan terdapat makanan yang dinamakan dengan apem, konon filosofi nama ape mini berasal dari kosakata Arab al-'afw ( العفو (). Dikarenakan lidahnya orang Jawa sukar mengucapkan kata tersebut dengan logat Arab, maka yang digunakan adalah apem (baca" al-'afw). ${ }^{29}$ Artinya adalah memintakan maaf kepada para leluhur, agar mereka mendapatkan tempat yang baik di sisi Allah Swt., dengan dilimpahi berbagai kenikmatan di Surga.

Kue apem dalam tradisi megengan juga mempunyai makna bahwa, saling memaafkan adalah satu di antara ajaran Islam yang luhur dan mulia. Meminta maaf kepada orang lain jika berbuat kesalahan, menurut Islam adalah perbuatan baik dan suatu keharusan. Akan tetapi memaafkan, atau memberi maaf orang lain yang mempunyai kesalahan kepada kita adalah suatu perbuatan mulia. Dalam sebuah hadis yang diriwayatkan oleh Abu Hurairah r.a, bahwasanya Rasulullah saw bersabda: "Musa bin Imran a.s, berkata: Wahai Tuhanku diantara hamba-hamba-Mu, siapakah orang yang paling mulia dalam pandangan-Mu? Allah Azza Wajalla menjawab: Orang yang memaafkan walaupun ia mampu membalas.” (HR. Imam Baihaqi)

Sementara itu, menurut M. Quraish Shihab, al-'afw terambil dari akar kata yang terdiri dari huruf 'ain, fa dan wauw. berarti "menghapus dan membinasakan serta mencabut sesuatu" karena yang memaafkan menghapus bekas-bekas luka di hatinya. Bukanlah memaafkan namanya, apabila masih ada tersisa bekas luka itu didalam hati, bila masih ada dendam yang membara. Boleh jadi, ketika itu apa yang dilakukan masih dalam tahap "masih menahan amarah". Usahakanlah untuk menghilangkan noda-noda itu, sebab dengan begitu kita baru bisa dikatakan telah memaafkan orang lain. ${ }^{30}$

${ }^{29}$ Video Ceramah dari KH. Anwar Zahid (Bojonegoro), Tentang Haul di Gresik; KH. Masyhudi (Kediri), Tentang Haul Tarekat al-Qodiriyah wa Naqsyabandiyah di Magetan di Youtube.

${ }^{30}$ M. Quraish Shihab, Op. Cit, 364. 
Dalam al-Qur'an, perintah untuk memaafkan orang lain, antara lain terdapat dalam beberapa ayat berikut, tersebut dalam Surat al-A'raf/7: 199, alNur/22: 24.

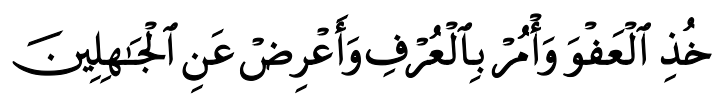

Artinya: "Jadilah Engkau (orang yang) Pema'af dan suruhlah orang mengerjakan yang ma'ruf, serta berpalinglah dari pada orang-orang yang bodoh". (Q.S Surat al-A'raf/7: 199)

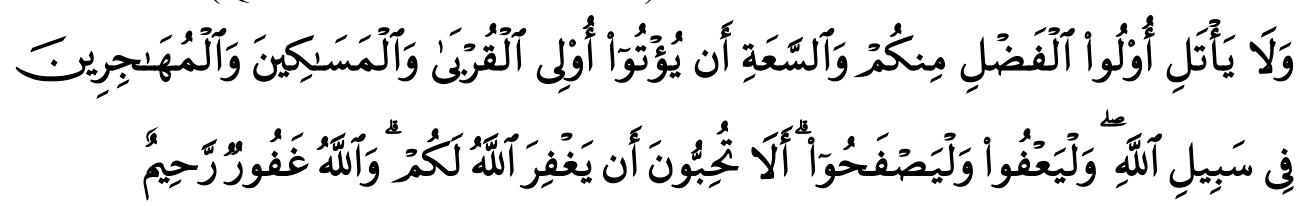

Artinya: "Dan janganlah orang-orang yang mempunyai kelebihan dan kelapangan di antara kamu bersumpah bahwa mereka (tidak) akan memberi (bantuan) kepada kaum kerabat(nya), orang-orang yang miskin dan orang-orang yang berhijrah pada jalan Allah, dan hendaklah mereka mema'afkan dan berlapang dada. Apakah kamu tidak ingin bahwa Allah mengampunimu? dan Allah adalah Maha Pengampun lagi Maha Penyayang" (Q.S al-Nur/22: 24).

Dua ayat di atas memerintahkan manusia untuk saling memaafkan, dan terlihat memberikan posisi tinggi bagi pemberi maaf. Memaafkan seseorang yang kita tidak mampu membalasnya adalah baik dan sedikit wajar, karena posisi kita pada saat itu lemah. Sementara memaaf-kan seseorang yang kita mampu untuk membalasnya adalah lebih baik dan lebih mulia karena pada saat itu posisi kita kuat dan bisa melakukan apa saja. Karena itu pula, pemaaf dijadikan salah satu ciri (tanda) orang yang bertaqwa.

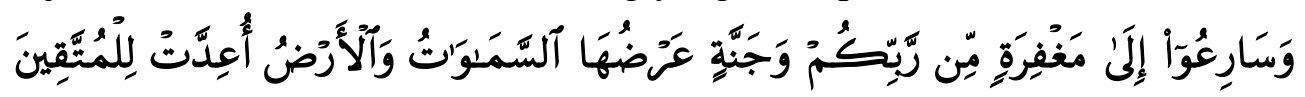

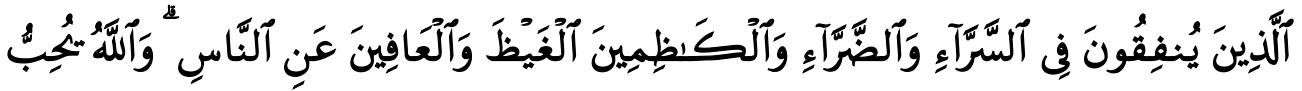

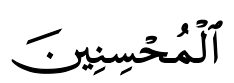

Artinya: "Dan bersegeralah kamu kepada ampunan dari Tuhanmu dan kepada surga yang luasnya seluas langit dan bumi yang disediakan untuk orang-orang yang bertakwa. (Yaitu) orang-orang yang menafkahkan (hartanya), baik di waktu lapang maupun sempit, dan orang-orang yang menahan amarahnya dan mema'afkan (kesalahan) orang. Allah menyukai orang-orang yang berbuat kebajikan." (Q.S Ali Imran/3: 133-134)

Ketika menafsirkan ayat di atas, M.Quraish Shihab ${ }^{31}$ dalam tafsirnya alMisbah mengatakan, bahwa dalam konteks menghadapi kesalahan orang lain Allah swt menunjukkan tiga kelas manusia atau jenjang sikapnya.

${ }^{31}$ M.Quraish Shihab, Tafsir al-Misbah, Vol. 2, (Jakarta: Lentera hati, 2006), h. 207 
Pertama, yang mampu menahan amarah (al-Kazhimin), yang bermakna penuh dan menutupnya dengan rapat, seperti wadah yang penuh dengan air lalu ditutup rapat agar tidak tumpah. Ini mengisyaratkan bahwa perasaan tidak bersahabat masih memenuhi hati yang bersangkutan, pikirannya masih menuntut balas, tetapi ia tdak memperturutkan ajakan hati dan pikiran itu, ia menahan amarah. Ia menahan diri sehingga tidak mencetuskan kata-kata buruk atau perbuatan negatif. Kedua, yaitu memaafkan yang berarti menghapus. Seseorang yang memaafkan orang lain adalah yang menghapus bekas luka hatinya akibat kesalahan yang dilakukan orang lain terhadapnya. Kalau dalam peringkat pertama di atas, yang bersangkutan baru sampai pada tahap menahan amarah, kendati bekas-bekas luka hati itu masih memenuhi hatinya, maka pada tahap ini, yang bersangkutan telah menghapus bekas-bekas luka hati itu. Kini seakan-akan tidak pernah terjadi satu kesalahan atau suatu apapun. Namun, karena pada tahap ini, seakan-akan tidak pernah terjadi sesuatu, maka boleh jadi juga tidak terjalin hubungan. Ketiga, untuk mencapai tingkat ini, Allah mengingatkan bahwa yang disukainya adalah orang-orang yang berbuat kebajikan, yakni bukan yang sekadar menahan amarah atau memaafkan, tetapi justru yang berbuat baik kepada yang pernah melakukan kesalahan. Semua orang bisa bersabar apabila ia terpaksa bersabar karena tidak memiliki kemampuan lain untuk membalas. Tetapi yang lebih sempurna adalah apabila ia mampu bersabar padahal ia mempunyai kekuatan untuk marah atau melakukan pembalasan.

Satu hal yang patut dicermati pada Q.S al-Imaran/3: 133-134 di atas ialah pada penekanan "wal ‘afiina ‘aninnas (memberi maaf kepada sesama manusia)" bukan "meminta maaf". Itu karena pada kenyataannya, acapkali dijumpai orang yang amat mudah meminta maaf kendati itu tak lebih sekadar basa-basi. Sebaliknya justru berat dan sulit untuk mau rela memberi maaf. Padahal memberi maaf memiliki maksud-maksud yang suci, serta berimplikasi psikologis sangat mendalam. Sifat pemaaf merupakan penjelmaan lahiriah dari kehendak dan mawas diri yang kuat, serta perpaduan antara keteguhan hati dan kekuatan pikiran. Orang yang senantiasa memberi maaf akan merasakan ketenangan batin yang sedemikian indah. Itu terjadi lantaran seluruh tekanan jiwa yang menyumbat segenap pembuluh darah seakan-akan terbuka. Darinya akan segera terasa, bagaimana potensi rohaniah kita menjadi begitu bertenaga sehingga sanggup membebaskan diri dari tirani hawa nafsu. Memaafkan kekurangan orang lain memang bukan pekerjaan ringan. Apalagi bagi mereka yang watak dan karakternya telah dipasung sedemikian rupa oleh kebencian, kekerasan, dan dendam. Selain berpengaruh pada jiwa si pemberi maaf tadi, sifat pemaaf juga akan berpengaruh kuat pada orang yang dimaafkan. Sampaisampai mampu merubah pikiran serta perilakunya. Apalagi jika ia adalah seorang musuh. Begitu banyak kasus mengenai hubungan yang renggang dan bermusuhan menjadi baik karena sifat pemaaf, kebencian dan per-musuhan yang telah berakar sangat dalam berubah menjadi kedamaian dan ketaatan yang menghiasi diri dan pemikirannya. Ketika Anda dirugikan orang lain, Anda memiliki kesempatan yang baik untuk memaafkan dan menikmati perasaan batin atas sifat yang mulia ini. Kita diajarkan untuk memaafkan 
musuh-musuh kita. Melakukan tindakan balas dendam terhadap lawan, akan menempatkan diri pada tempat yang sama dengan musuh, karena telah melakukan hal sama dengannya, bahkan telah menjadi pengikutnya. Tetapi Anda akan mendapatkan kemuliaan jika Anda mau memaafkan kesalahannya. Menghadirkan sifat pemaaf memaksa musuh-musuh untuk bertekuk lutut yang akan memiliki pengaruh psi-kologis dan mengajarkan sifat rendah hati. Karena itu adalah wajib bagi kita untuk bersikap baik ketika orang lain melanggar, karena kebaikan merupakan kebajikan surgawi, yang dengan itu alam semesta dan para peng-huninya dapat hidup dalam kedamaian dan keharmonisan.

Ketika seseorang berusaha untuk menjadi Pemaaf berarti ia telah berusaha untuk meniru sifat Allah "Al-âfuwwu" (Yang Maha Memaafkan). Nabi Muhammad SAW adalah figur yang paling patut menjadi contoh sebagai orang yang pemaaf. Lihatlah dalam sejarah, bahwa setelah pembebasan Makkah (Fathu Makkah), dihadapan orang-orang yang selama ini gigih memusuhinya, Rasu-lullah berkata : "Wahai orang-orang Quraisy. Menurut pendapat kamu sekalian apa kira-kira yang akan aku perbuat terhadapmu sekarang?" Jawab mereka: "Yang baik-baik saudara kami yang pemurah, sepupu kami yang pemurah." Mendengar jawaban itu Nabi kemudian berkata: "Pergilah kamu semua, sekarang kamu sudah bebas." Begitu luhur jiwa Nabi, karena dengan ucapan itu kepada kaum Quraisy dan kepada seluruh penduduk Makkah, beliau telah memberikan amnesty (ampunan) umum. Padahal saat itu nyata mereka tergantung hanya di ujung bibirnya dan kepada wewenangnya atas ribuan bala tentara Muslim yang bersenjata lengkap yang ada bersamanya. Mereka dapat mengikis habis penduduk Makkah dalam sekejap hanya tinggal menurut perintah dari Nabi. Dengan pengampunan dan pemberi maaf itu, jiwa Nabi telah melampaui kebesaran yang dimilikinya, melampaui rasa dengki dan dendam di hati, menunjukkan bahwa beliau bukanlah manusia yang mengenal permusuhan, atau yang akan membangkitkan permusuhan di kalangan umat manusia. Beliau bukan seorang tiran, yang mau menunjukkan sebagai orang yang berkuasa. Padahal Nabi mengenal betul, kejahatan orangorang yang diampuninya itu. Siapa-siapa di antara mereka yang berkomplot untuk membunuhnya, yang telah menganiayanya dan menganiaya para pengikutnya. Mereka melemparinya dengan kotoran bahkan dengan batu saat mengajak manusia ke jalan Allah. Begitu pemaafnya Rasulullah sekalipun itu kepada orang yang selalu menebar permusuhan, menteror dan mengancam keselamatannya. Rasulullah begitu pemaaf, Tuhan juga Maha mengampuni kesalahan hamba-Nya. Mengapa kita manusia biasa susah sekali memberikan kemaâfan?

Akhirnya bagi orang yang bersifat pemaaf Allah swt berfirman:

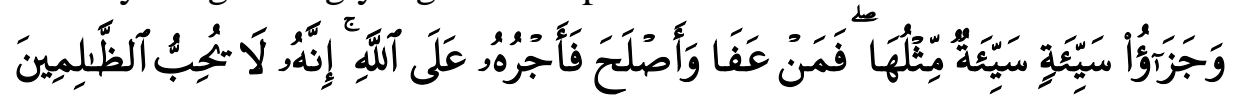

Artinya: "Dan Balasan suatu kejahatan adalah kejahatan yang serupa, Maka barang siapa memaafkan dan berbuat baik Maka pahalanya atas (tanggungan) Allah. Sesungguhnya Dia tidak menyukai orang-orang yang zalim.” (Q.S al-Syura/42: 40) 


\section{Tradisi Megengan Sebagai Wujud Sedekah}

Secara umum, tradisi megengan ini merupakan pengamalan terhadap anjuran Nabi Muhammad Saw., untuk bersedekah makanan kepada orang lain. Misalnya anjuran Rasulullah Saw., untuk memperbanyak kuah ketika membuat makanan agar dapat diberikan kepada tetangga sekitar. Sebagaimana disebutkan dalam sebuah hadits Nabi:

Artinya: "Dari Abi Dzar ra. ia berkata: "Rasulullah Saw. bersabda,

"Wahai Abu Dzar, jika kamu memasaka kuah, maka perbanyaklah airnya, dan bagi-bagikanlah kepada tetanggamu."

Hadits tersebut berisi anjuran untuk bersedekah dengan sesuatu yang sederhana dan disenangi oleh tetangga. Masalah sedekah itu bisa berwujud kuah, bubur, nasi kuning, atau apem (baca: kue tradisional khas Jawa) seperti yang dilakukan oleh sebagian masyarakat pada sehari menjelang Ramadhan (baca: megengan). Hal yang sama juga dilakukan oleh masyarakat Makkah dan Madinah bersedekah roti, laban, atau 'ashir (sari buah) pada musim haji secara tetap setiap tahun. Perbuatan ini juga merupakan kebiasaan ulama' salaf dari kalangan tabi'in. mereka senantiasa memberikan hadiah (berupa makanan dan lainnya) kepada sahabatnya, walaupun orang diberi itu bukanlah prang yang serba kekurangan.

Syaikh al-Arif al-Sya'rawi mengatakan: ${ }^{33}$

"Bahwa para tabi'in memiliki kebiasaan memberikan hadiah kepada saudarasaudaranya. Mereka berkata, "Kami tahu bahwa engkau tidak membutuhkan benda yang akmi berikan ini. Tetapi, kami memberikannya kepadamu agar kamu tahu bahwa kami masih peduli dan menganggapmu sebagai sahabat."

Sesungguhnya sedekah menumbuhkan rasa kasih sayang dalam hati, dan membantu menghilangkan selubungnya. Allah Swt., berfirman:

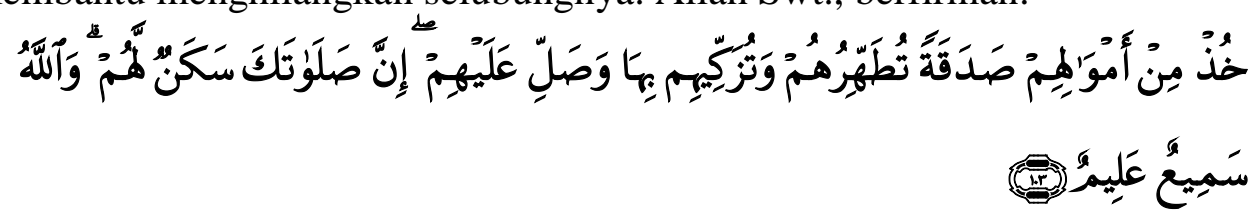

Artinya: "Ambillah zakat dari sebagian harta mereka, dengan zakat itu kamu membersihkan dan mensucikan mereka dan mendoalah untuk mereka. Sesungguhnya doa kamu itu (menjadi) ketenteraman jiwa bagi mereka. dan Allah Maha mendengar lagi Maha mengetahui.” (QS. At-Taubah: 103)

Ketika menafsirkan ayat diatas Imam Asy-Sya'rawi mengatakan: ini adalah sedekah yang tidak wajib. Sebab, jika yang dimaksud adalah sedekah wajib, niscaya tidak membutuhkan perintah baru. Tetapi ini adalah sedekah kafarat (penebus dosa). ${ }^{34}$ Oleh karena itu, para ulama selalu mengajarkan untuk memperbanyak sedekah sepanjang waktu, khususnya pada waktu-waktu

\footnotetext{
${ }^{32}$ H.R Imam Muslim, no. 4785

${ }^{33}$ Syaikh al-Arif al-Sya'rawi, Faidh al-Qadir, Juz III, h. 272

${ }^{34}$ Muhammad Mutawalli Asy-Sya'rawi, Ishlahul Qulub, (Depok: Keira Publishing, 2015), terj. oleh Mujahidin Muhayan, h. 126
} 
yang penting. Imam an-Nawawi menjelaskan: "para ulama syafi'iyyah berkata, disunnahkan untuk memperbanyak sedekah ketika menghadapi urusan-urusan penting". 35

Sementara itu Rasulullah Saw., berpesan kaitannya dengan sedekah ini:

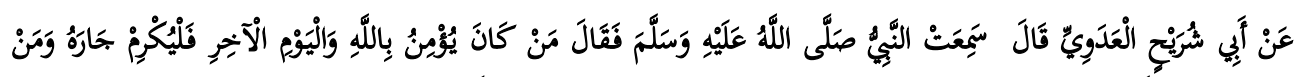

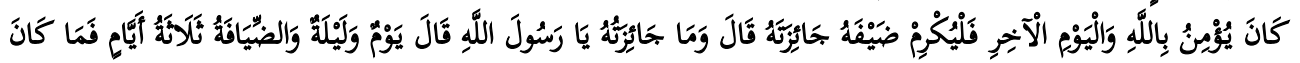

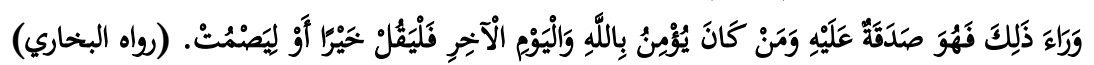

Artinya: Dari Abi Syuraikh al-'Adawi berkata, aku mendengar Nabi SAW bersabda: Siapa yang beriman kepada Allah dan hari akhirat hendaklah ia memuliakan jiran tetangganya, siapa yang beriman kepada Allah dan hari akhirat hendaklah ia memuliakan tamunya pada hari kedatangannya satu hari satu malam, dan menghormatinya sebagai tamu selama tiga hari. Adapun lebih dari itu berarti sedekah. Dan siapa yang beriman kepada Allah dan hari akhirat hendaklah ia berkata baik atau lebih baik ia diam. (H.R Bukhari $^{36}$

Dari hadits diatas mampu diterangkan bahwa, substansi ajaran Islam tidak hanya memelihara hubungan baik kepada Tuhan (Allah) (habl min Allah) akan tetapi juga memelihara hubungan baik kepada sesama manusia (habl min al-Nas). Islam tidak menginginkan ketidak seimbangan antara keduanya. Diantara akhlak terpuji yang diajarkan Islam sebagai manifestasi dari menjaga hubungan baik kepada sesama manusia adalah memuliakan tetangga. Hadis di atas menunjukkan bahwa perbuatan memuliakan tetangga merupakan syarat atau bagian dari kesempurnaan iman.

Tetangga adalah orang-orang yang tinggal berdampingan atau berdekatan dengan tempat tinggal kita berada. Jadi, tetangga menjadi bagian yang penting dalam kehidupan bermasyarakat. Tetanggalah yang pertama akan memberikan pertolongan jika sebuah keluarga mengalami musibah atau ingin mengadakan sebuah hajatan. Karena itulah Islam telah memberikan tuntunan bagaimana berperilaku yang seharusnya kepada jiran tetangga. Dalam sebuah riwayat hadis Nabi SAW dinyatakan:

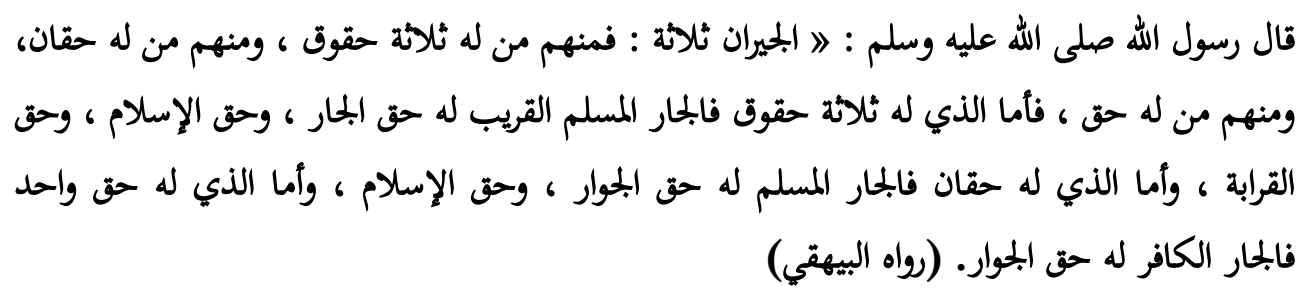

${ }^{35}$ Imam an-Nawawi, Al-Majmu' Syarh al-Muhadzdzab, Juz VI, h. 233

${ }^{36}$ Bukhari, Juz IV, Op. Cit, h. 63. Hadis ini juga diriwayatkan oleh Muslim, Kitab Jami, Shahih bab Luqthah: 14, bab Iman: 74,75,77; Abu Dawud, Kitab Sunan bab Ath'imah:5; Turmudzi, Kitab Sunan, bab Birr: 43, bab Qiyamah: 50; Ibn Majah, Kitab Sunan bab Adab: 5; alDailami, Kitab Sunan bab Ath'imah: 5; Malik, Kitab Muwathta' bab Shifat al-Nabi: 22 dan; Ahmad bin Hambal, Kitab Musnad jilid II: 174, 267,269. Lihat, A.J Wensink, jilid V, Op. Cit, h. 558 
Artinya: "Rasulullah SAW bersabda: "Tetangga itu ada tiga macam, diantara mereka ada yang mempunyai tiga hak, dan yang mempunyai dua hak, dan ada yang mempunyai satu hak. Tetangga yang mempunyai tiga hak adalah tetanggamu yang masih kerabat dan muslim, dan tetanggamu yang mempunyai dua hak adalah tetanggamu yang muslim, dan tetangganu yang hanya mempunyai satu hak adalah tetangga yang dzimmi" (H.R Baihaqi). ${ }^{37}$

Juga dalam hadis lain:

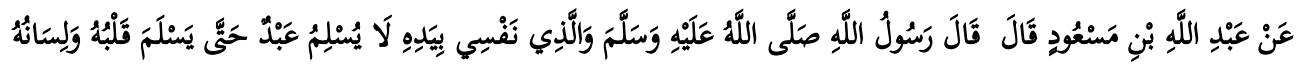

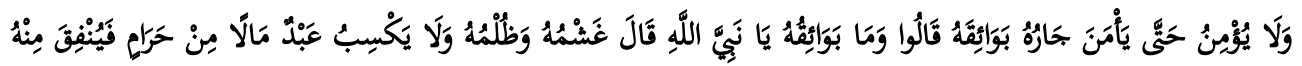

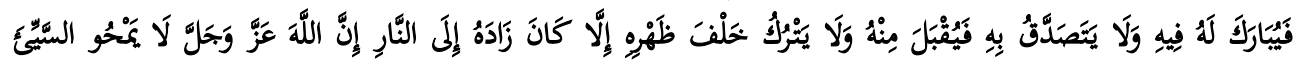

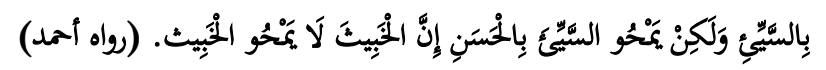

Artinya: Dari Abd Allah bin Mas'ud r.a berkata, bersabda Rasulullah SAW : "Demi dzat yang jiwaku berada di dalam genggaman-Nya, tidak Islam seorang hamba sehingga orang-orang selamat dari (gangguan) hati, lisan, dan tangannya, dan seseorang tidak beriman sehingga tetangganya aman dari gangguan-gangguannya. Kami bertanya, wahai Rasulullah apakah gangguan-gangguan itu? Beliau bersabda, tipuan dan kezalimannya”. (H.R Ahmad) $)^{38}$

Maksud hadis di atas adalah, jika tetangga itu masih tremasuk kerabat dan muslim, maka ia mempunyai hak sebagai kerabat, hak sesabagi sesama muslim dan hak sebagai tetangga. Jika tetangga itu muslim tetapi bukan kerabat, maka ia mempunyai dua hak yaitu hak sebagai sesama muslim dan hak sebagai tetangga. Sedangkan jika tetangga itu bukan muslim dan bukan kerabat maka ia hanya mempunyai satu hak, yaitu hak sebagai tetangga. Jadi menghormati dan memuliakan tetangga tidak hanya sebatas pada jiran tetangga yang seagama tapi juga yang tidak seagama. Artinya, jika sebuah keluarga muslim ber-tetangga dengan non muslim, maka tetangga yang non muslim tersebut mempunyai hak untuk untuk dihormati dan dimuliakan.

Menurut pandangan Islam, menghormati dan memuliakan tetangga hukumnya adalah wajib. Kewajiban ini antara lain dapat dilihat dalam pernyataan al-Qur'an dalam bentuk perintah sebagai berikut:

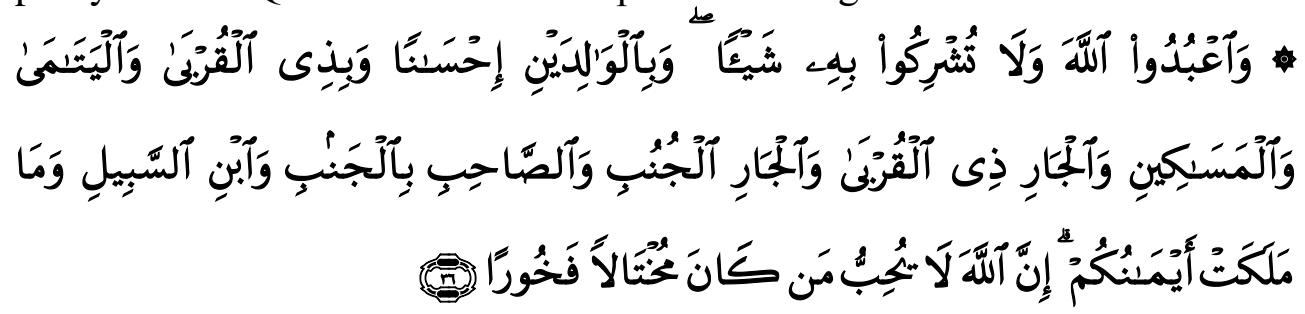

\footnotetext{
${ }^{37}$ Abu Laits al-Samarqandi, Op. Cit. h. 246

${ }^{38}$ Ibid., h. 242
} 
Artinya: "Sembahlah Allah dan janganlah kamu mempersekutukan-Nya dengan sesuatupun. dan berbuat baiklah kepada dua orang ibu-bapa, karib-kerabat, anak-anak yatim, orang-orang miskin, tetangga yang dekat dan tetangga yang jauh, dan teman sejawat, Ibnu sabil dan hamba sahayamu. Sesungguhnya Allah tidak menyukai orang-orang yang sombong dan membangga-banggakan diri." (Q.S al-Nisa/4: 36)

Perintah beruat baik kepada tetangga pada ayat di atas, terlihat dipararelkan dengan berbuat baik kepada dua orang tua dan karib keluarga. Hal itu, setidaknya menunjukkan bahwa al-Qur'an memberikan perhatian khusus tentang persoalan berjiran tetangga. Sejalan dengan makna ayat di atas, suatu riwayat hadis menyatakan:

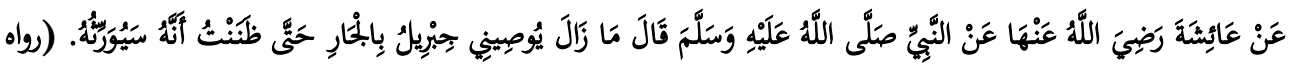

البخاري)

Artinya: "Dari A'isyah r.a, Nabi SAW bersabda: "Malaikat Jibril senantiasa memberi wasiat kepadaku mengenai tetangga, sehingga Aku menyangka bahwa tetangga itu akan diberi wasiat." (H.R. Bukhari) ${ }^{39}$

Dalam hal menghormati dan memuliakan tetangga ini, maka setidaknya ada beberapa hal yang harus diperhatikan: (1) Jika ia ingin berhutang (meminjam) sesuatu maka berilah pinjaman (hutangilah); (2) Jika ia sakit, maka harus menjenguknya; (3) Jika ia minta ban-tuan maka bantulah; (4) Jika ia ditimpa musibah maka hiburlah; (5) Jika ia mendapatkan kesenangan maka ucap-kan selamat kepadanya; (6) Jika ia pergi maka jagalah (rumah dan keluarganya); (7) Jika ia mati maka antar-kanlah jenazahnya, dan; (8) Jangan mengganggunya dengan bau masakanmu, kecuali ia diberi masakan itu.

Lebih lanjut menurut al-Samarqandi, bahwa setiap muslim hendaknya sabar terhadap gangguan tetangga dan tindak menyakiti tetangganya serta tetangga merasa aman dari tetangga itu sendiri. Terdiri atas tiga hal yaitu, aman dari gangguan tangan, lisan dan aurat. Aman dari gangguan tangan yaitu seandainya tetanggamya berada di pasar, lantas ingat bahwa dompetnya tertinggal di rumah, maka tetangga itu sedikitpun tidak merasa curiga. Aman dari gangguan lisan yaitu tidak mengucapkan perkataan yang seandainya didengar oleh tetangganya ia akan diam, atau jika perkataan itu disampaikan kepada tetangga maka ia akan merasa malu. Sedangkan aman dari gangguan aurat yaitu seandainya sedang berpergian, lalu diberi tahu bahwa tetangganya masuk ke dalam rumahnya maka hatinya akan merasa tenang dan gembira. ${ }^{40}$ Rasulullah SAW dalam hadisnya menyatakan:

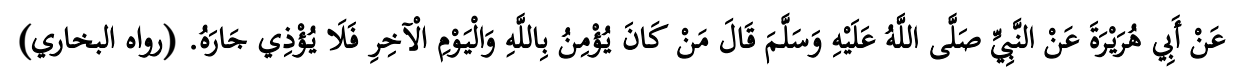

\footnotetext{
${ }^{39}$ Al-Bukhari, Juz IV, Op. Cit, h. 63

${ }^{40}$ Abu Laits al-Samarqandi, Op. Cit, h. 247-248
} 
Artinya: Dari Abi Hurairah r.a Nabi SAW bersabda: " Siapa yang beriman kepada Allah dan hari akhirat maka janganlah ia menyakiti tetangganya." (H.R. Bukhari). ${ }^{41}$

Tradisi Megengan merupakan momentum yang tepat untuk melaksanakan sedekah, ${ }^{42}$ yang jatuh pada bulan Sya'ban, karena bulan ini adalah bulan persiapan untuk menghadapi bulan Ramadhan, dimana semua amal perbuatan manusia yang diperintahkan pada bulan Ramadhan juga dianjurkan pada bulan Sya'ban. Hafidz Ibn Rajab al-Hanbali mengatakan: ${ }^{43}$ "Karena Sya'ban itu merupakan persiapan menghadapi bulan Ramadhan, maka semua amaliah yang dikerjakan pada bulan Ramadhan juga dianjurkan untuk diamalkan pada bulan Sya'ban, seperti puasa dan membaca al-Qur'an. Tujuannya adalah agar jiwa benar-benar siap untuk menghadapi bulan Ramadhan."

\section{Tradisi Megengan Sarana Meneguhkan Al-Akhwah dan Al-Shilah al- Rahim (Persaudaraan dan Kasih Sayang)}

Di dalam beberapa hadits, Rasulullah Saw. menerangkan akan persoalan ini, diantaranya adalah sebagai berikut:

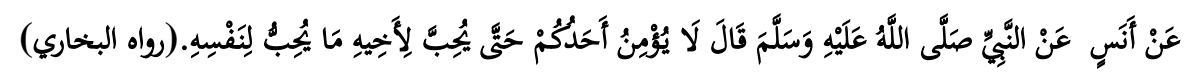

Artinya: "Dari Anas r.a, dari Nabi SAW bersabda: " Tidak beriman salah seorang kamu sehingga ia mencintai saudaranya sebagaimana ia mencintai dirinya sendiri." (H.R Bukhari) ${ }^{44}$

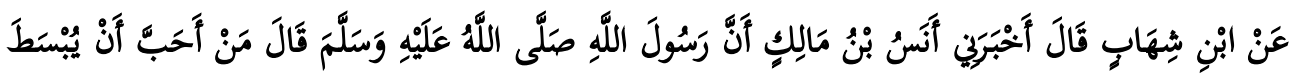

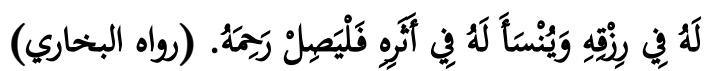

Artinya: "Dari Anas bin Malik bahwa Rasulullah SAW bersabda: " Siapa yang suka rezekinya akan diperluas dan umurnya bertambah panjang maka hendaklah ia menjalin shilaturrahim." (H.R Bukhari) ${ }^{45}$

Sebagai sebuah keyakinan, Islam sangat menjunjung tinggi nilai persaudaraan, kasih sayang dan saling mencintai antar sesama manusia,

\footnotetext{
${ }^{41}$ Al-Bukhari, Loc. Cit
}

${ }^{42}$ Bukan berarti di hari atau bulan yang lain kemudian kita tidak melakukan sedekah, ini merupakan pehaman yang perlu diluruskan.

${ }^{43}$ Ibnu Rajab al-Hanbali, Latha 'if al-Ma'arif, h. 258

${ }^{44}$ Al-Bukhari, Jami’ Shahih al-Bukhari, Juz I, Beirut: Dar al-Fikri, 2006, h. 11. Hadis ini juga diriwayatkan oleh Muslim, Kitab Jami' Shahih bab Iman: 71 dan 72; Turmudzi, Kitab Musnad bab Qiyamah: 59; al-Nasa'i, Kitab Sunan bab Iman: 19; Ibn Majah, Kitab Sunan bab Muqaddimah: 9 dan bab Janaiz: 1; al-Dailami, Kitab Sunan bab isti'dzan: 5, dan bab Riqaq: 29, dan; Ahmad bin Hanbal, Kitab Musnad jilid I: 89. Lihat, A.J Wensink, jilid I, Op. Cit, h. 407

${ }^{45}$ Ibid., (al-Bukhari), Jilid. IV, h. 59. Juga diriwayatkan oleh Muslim, Kitab Jami' Shahih bab al-Birr: 20, 21; dan Abu Dawud, Kitab Sunan bab Zakat: 45. Lihat. A.J Wensink, (ibid), h. 179 
terlebih khusus terhadap sesama Muslim. Sedemikian penting dan tingginya perhatian Islam tentang menjalin persaudaraan dan cinta kasih sayang sehingga persoalan ini dikaitkan dengan kesempurnaan iman. Bentuk acara megengan, selain menumbuhkan kegemaran untuk melaksanakan sesekah dan memuliakan tetangga, ternyata juga mempunyai fungsi melekatkan nilai-nilai persaudaraan diantara sesama muslim hingga antar umat manusia. Sebab, dibanyak tempat ritual pelaksanaan tradisi megengan ini dihadiri oleh orangorang yang berlainan agama (baca: Kristen-Katolik), sebagaimana yang terjadi di Kelurahan Ngagel Rejo, Surabaya dan Kabupaten Rejang Lebong, Bengkulu.

Hubungan persaudaraan sesama Muslim, dalam al-Qur'an diistilahkan dengan "ikhwah atau akhwah". Istilah "ikhwah atau akhwah" ini terambil dari kata "akhun" yang artinya saudara laki-laki. Maksudnya seseorang yang mempunyai hubungan dengan seseorang lain secara atau berdasarkan nasab (darah atau keturunan). Dalam al-Qur'an Allah SWT berfirman:

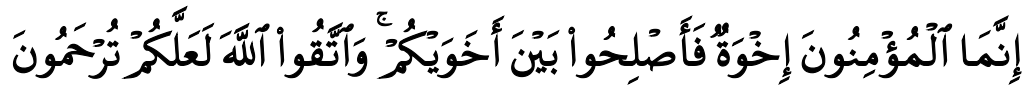

Artinya: "Orang-orang beriman itu Sesungguhnya bersaudara. sebab itu damaikanlah (perbaikilah hubungan) antara kedua saudaramu itu dan takutlah terhadap Allah, supaya kamu mendapat rahmat." (Q.S alHujarat/49: 10)

Dalam spektrum yang lebih luas (secara universal), Islam bahkan memandang bahwa seluruh manusia merupakan satu kesatuan (ummatan wahidah). Dalam al-Qur'an Allah SWT berfirnan:

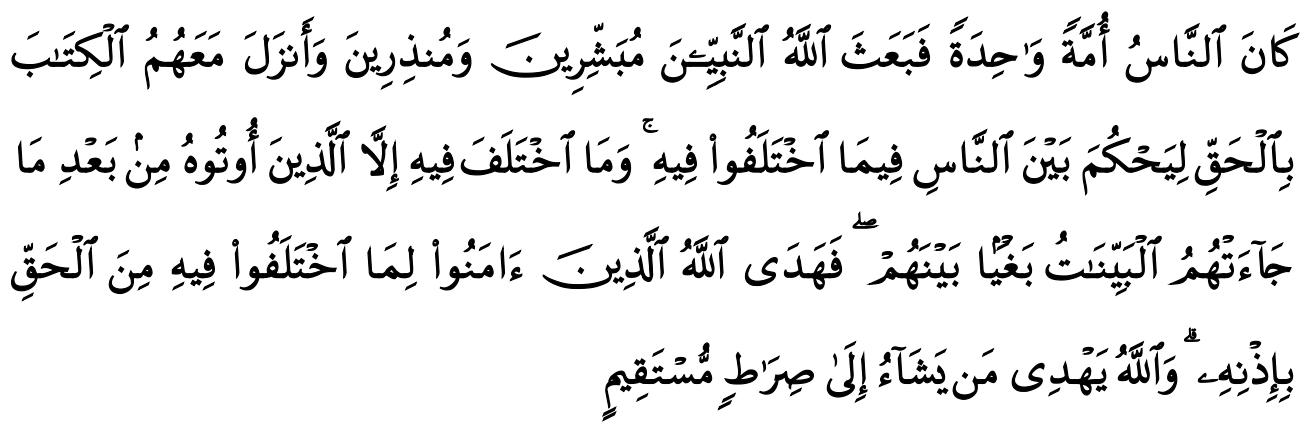

Artinya: "Manusia itu adalah umat yang satu. (setelah timbul perselisihan), maka Allah mengutus Para Nabi, sebagai pemberi peringatan, dan Allah menurunkan bersama mereka kitab yang benar, untuk memberi keputusan di antara manusia tentang perkara yang mereka perselisihkan. tidaklah berselisih tentang kitab itu melainkan orang yang telah didatangkan kepada mereka Kitab, Yaitu setelah datang kepada mereka keterangan-keterangan yang nyata, karena dengki antara mereka sendiri. Maka Allah memberi petunjuk orang-orang yang beriman kepada kebenaran tentang hal yang mereka perselisihkan itu dengan kehendak-Nya. dan Allah selalu memberi petunjuk orang yang dikehendaki-Nya kepada jalan yang lurus." (Q.S alBaqarah/2: 213) 
Pada ayat di atas, al-Qur`an menyatakan bahwa manusia pada hakikatnya umat yang satu (ummatan wahidah). Dikatakan demikian karena seluruh manusia mengakui bahwa mereka berasal dari bapak dan ibu yang satu, yaitu Adam dan Hawa. Dari dua manusia yang pertama itulah muncul kerurunannya yang terdiri dari suku dan bangsa, yang setiap suku dan bangsa memiliki budaya (culture) yang berbeda antara satu dan lainnya.

Pada ayat lain al-Qur'an menyatakan:

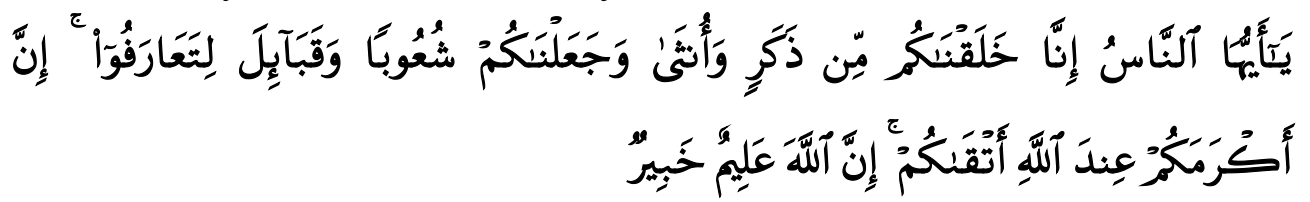

Artinya: "Hai manusia, Sesungguhnya Kami menciptakan kamu dari seorang laki-laki dan seorang perempuan dan menjadikan kamu berbangsa - bangsa dan bersuku-suku supaya kamu saling kenal-mengenal. Sesungguhnya orang yang paling mulia diantara kamu disisi Allah ialah orang yang paling taqwa diantara kamu. Sesungguhnya Allah Maha mengetahui lagi Maha Mengenal.” (Q.S al-Hujarat/49: 13)

Perbedaan karakteristik dan budaya tentu berpotensi munculnya perselisihan, pertikaian bahkan permusuhan. Untuk menghindari dampak negatif dari perbedaan itulah al-Qur`an mengingatkan bahwa antara sesama manusia, terlepas apapun ras dan keyakinannya, sesungguhnya memiliki hubungan persaudaran (ikhkwah) yaitu berasal dari asal keturunan yang sama dan satu. Salah satu upaya untuk menjaga dan mewujudkan rasa persaudaran dan kesatuan ummat wahidah, maka perlu ditumbuh kembangkan dan disuburkan sifat dan perilaku menjalin hubungan kasih sayang yang dalam terminologi agama Islam disebut "shilat al-rahmi".

Secara bahasa istilah shilat al-rahim, terdiri dari kata shilat yang artinya hubungan, sedangkan al-rahim artinya kasih sayang. Shilat al-rahim berarti hubungan kasih sayang atau lazim juga diartikan hubungan kasih sayang. Dalam bahasa Arab, kata "al-rahim" berasal dari akar kata "rahima". Menurut Qurasih Shihab, semua kata yang terdiri dari huruf " $r a-h a-$ dan mim " mengandung makna kelemah lembutan, kasih sayang dan kehalusan. Dari akar kata inilah lahir kata rahman, rahim dan rahmat. ${ }^{46}$ Rahman dan Rahim merupakan salah satu dari nama-nama Allah (asma`u al-husna). Dua nama Allah ini adalah yang paling banyak disebut dalam al-Qur`an di banding namanama Allah lainnya. Ini menunjukkan bahwa yang lebih dominan pada diri Allah SWT adalah sifat Kasih Sayang-Nya (al-Rahman dan al-Rahim). ${ }^{47}$ Dikatakan dalam al-Qur`an bahwa rahmat dan kasih sayang Allah meliputi segala sesuatu.

${ }^{46}$ M.Quraish Shihab, Menyingkap Tabir Ilahi: Asma al-Husna Dalam Perspektif AlQur'an, Jakarta: Lentera Hati, 1999, h. 19

${ }^{47}$ Kata al-rahman disebut 57 kali, sedangkan al-rahim disebut 95 kali. Jika digabungkan maka keduanya berjumlah 152 kali. 


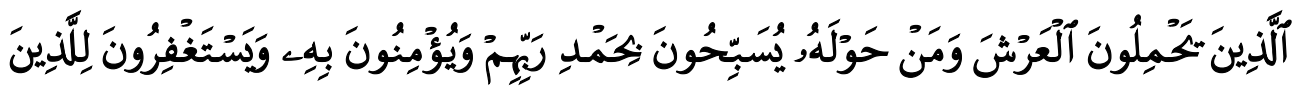

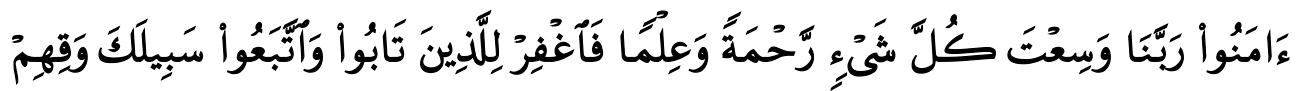 عَذَابَ أَلَْحِيم}

Artinya: “(malaikat-malaikat) yang memikul 'Arsy dan Malaikat yang berada di sekelilingnya bertasbih memuji Tuhannya dan mereka beriman kepada-Nya serta memintakan ampun bagi orang-orang yang beriman (seraya mengucapkan): "Ya Tuhan Kami, rahmat dan ilmu Engkau meliputi segala sesuatu, Maka berilah ampunan kepada orang-orang yang bertaubat dan mengikuti jalan Engkau dan peliharalah mereka dari siksaan neraka yang menyala-nyala," (Q.S al-Mu`min / 40: 7)

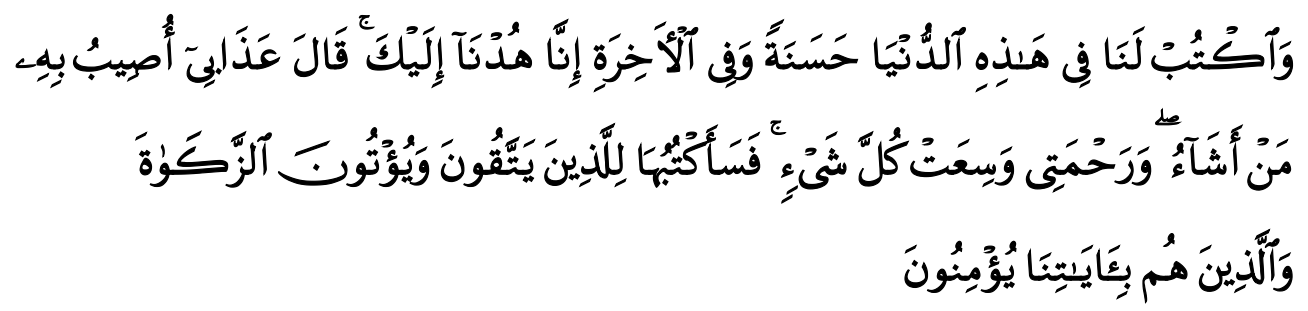

Artinya: "Dan tetapkanlah untuk Kami kebajikan di dunia ini dan di akhirat; Sesungguhnya Kami kembali (bertaubat) kepada Engkau. Allah berfirman: "Siksa-Ku akan Kutimpakan kepada siapa yang aku kehendaki dan rahmat-Ku meliputi segala sesuatu. Maka akan aku tetapkan rahmat$K u$ untuk orang-orang yang bertakwa, yang menunaikan zakat dan orangorang yang beriman kepada ayat-ayat kami". (Q.S al-A'raf/7: 156)

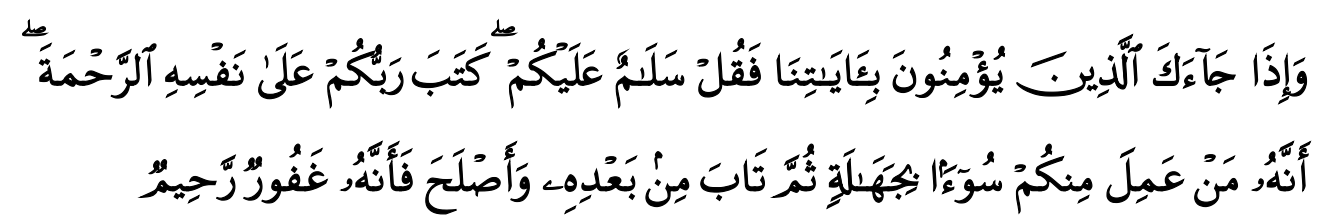

Artinya: "Apabila orang-orang yang beriman kepada ayat-ayat Kami itu datang kepadamu, Maka Katakanlah: "Salaamun alaikum. Tuhanmu telah menetapkan atas Diri-Nya kasih sayang, (yaitu) bahwasanya barang siapa yang berbuat kejahatan di antara kamu lantaran kejahilan, kemudian ia bertaubat setelah mengerjakannya dan Mengadakan perbaikan, Maka Sesungguhnya Allah Maha Pengampun lagi Maha Penyayang. (Q.S alAn'am /6: 54)

Demikianlah begitu besar dan luasnya rahmat dan kasih sayang Allah SWT, sehingga Dia sangat menyukai orang orang yang memiliki sifat kasih sayang, dan bahkan karenanya Allah berpesan agar manusia memiliki sifat atau akhlak mulia (karimah) ini. 


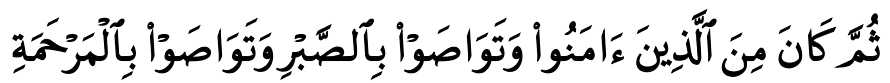

Artinya: "Dan Dia (tidak pula) Termasuk orang-orang yang beriman dan saling berpesan untuk bersabar dan saling berpesan untuk berkasih sayang”. (Q.S al-Balad/90: 17)

Sifat kasih sayang pada dasarnya adalah fitrah yang dianugerahkan Allah kepada semua makhluk ciptaan-Nya. Pada hewan sekalipun terdapat sifat kasih sayang sehingga rela berkorban jika anaknya diganggu. Terlebih lagi pada manusia sebagai makhluk yang paling sempurna, Allah telah meniupkan sifat kasih sayang dalam jiwa manusia yang dengannya dapat menjaga hubungan persaudaraaan. Karena itulah Islam sangat tidak menyukai orang yang memutuskan hubungan persaudaraan dan kasih sayang antar sesama manusia. Kepada orang yang melakukan pemutusan hubungan sesama manusia ini bahkan dinyatakan Nabi SAW tidak akan masuk surga.

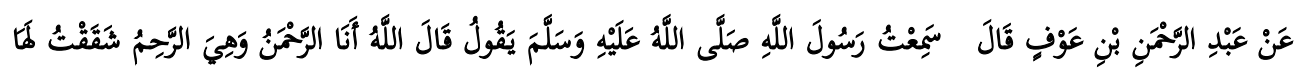

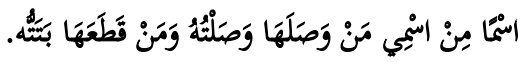
(رواه أبو داود)

Artinya: "Dari Abd al-Rahman bin 'Auf, aku mendengar Rasulullah SAW bersabda: "Aku adalah al-Rahman, Aku menciptakan rahim, Kuambilkan untuknya nama yang berakar dari nama-Ku. Siapa yang menyambungnya (silaturrahim) akan Ku-sambung (rahmat-Ku) untuknya dan siapa yang memutuskannya Kuputuskan (tahmat-Ku baginya)." (H.R Abu Dawud) ${ }^{48}$

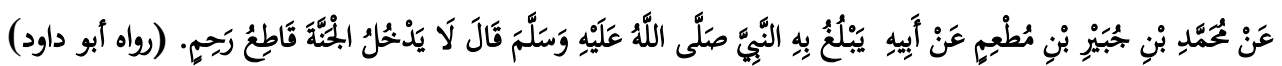
Artinya: Dari Muhammad bin Jubair bin Muth'im, dari ayahnya bahwa Nabi SAW bersabda: “ Tidak akan masuk surga orang yang memutuskan silaturahim. (H.R Abu Dawud) ${ }^{49}$

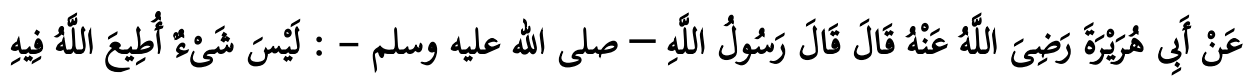

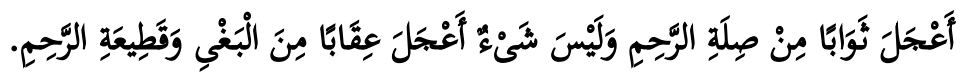

$$
\begin{aligned}
& \text { (رواه البيهقي) }
\end{aligned}
$$

Artinya: "Dari Abi Hurairah r.a berkata, Rasulullah SAW bersabda: “ Tidak ada pahala yang palimg disegerakan oleh Allah kecuali pahala shilaturrahim. Dan tidak ada dosa yang disegerakan oleh Allah kecuali marah dan memutuskan shilaturrahim." (H.R. Baihaqi) ${ }^{50}$

\footnotetext{
${ }^{48}$ Abu Dawud, Juz II, Op.Cit, h. 133

49 Loc. Cit.

${ }^{50}$ Baihaqi, Sunan al-Kubra, dalam CD Maktabah al-Syamilah
} 


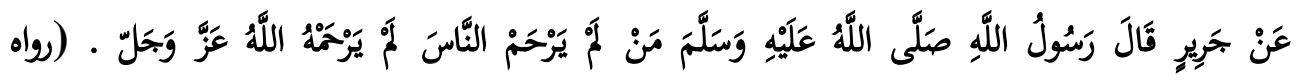 \\ الترمذي)}

Artinya: "Dari Jabir, bersabda Rasulullah SAW: "Siapa yang tidak berbelas kasih kepada manusia, nisacaya Allah tidak berbelas kasih pula padanya." (H.R Turmudzi) ${ }^{51}$

Sungguhpun demikian, naluri kasih sayang ini dapat tertutup jika terdapat hambatan-hambatan, misalnya karena pertengkaan, permusuhan, kerakusan, kedengkian dan lain-lain. Islam menginginkan agar silaturrahmi dan sifat belas kasih dikembangkan secara wajar, baik antara sesama umat yang seagama, sesama manusia meskipun berbeda agama dan keyakinan, bahkan lebih luas lagi belas kasih sayang kepada hewan-hewan sekalipun. Dengan demikian jika diperinci ruang lingkup silaturrahmi atau hubungan kasih sayang dan persaudaraan dapat diuraikan dalam beberapa tingkatan: (1) Hubungan persaudaraan (kasih sayang) dalam lingkungan keluarga; yaitu antara orang tua kepada anak, suami dan istri, dan antara orang yang bersaudara dalam berkeluarga; (2) Hubungan persaudaraan (kasih sayang) dalam lingkungan tetangga dan kampung; yaitu suatu pertalian persaudaraan yang timbul dan tumbuh karena hidup bersama suatu ling-kungan dan kampung; (3) Hubungan persaudaraan (kasih sayang) yang timbul akibat persamaan rumpun, suku bangsa, rasa senasib dalam perjuangan yang menyangkut kenegaraan; (4) Hubungan persaudaraan (kasih sayang) dalam lingkungan keagamaan; yaitu mencintai dan mengasihi sesama orang yang seagama, karena memandang suadara dalam akidah dan keyakinan; (5) Hubungan persaudaraan (kasih sayang) dalam bentuk kemanusiaan, yaitu mencintai sesama manusia atas dasar pengertian bahwa manusia adalam samasama berasal dari satu keturunan, asalnya satu bapak dan satu ibu, dan; (6) Hubungan persaudaraan (kasih sayang) kepada sesama makhluk (universal): misalnya mengasihi hewan dan tumbuh-tumbuhan. ${ }^{52}$

Menurut Hamzah Ya'kub ${ }^{53}$, ada banyak dampak positif yang muncul dari tertanamnya sifat kasih sayang dalam diri seseorang, antara lain:

Pertama, sifat pemurah (al-Shakha): yaitu sifat suka mengulurkan tangan kedemawanan kepada orang lain yang menghajatkannya. Di sini lahir perbuatan suka berinfak dan sedekah, yakni rela memebelanjakan harta bagi kepentingan keluarga dan amal sosial. Sikap ini termasuk akhlakul mahmudah. Kedua, sifat suka tolong menolong (al-ta'awun); yaitu sikap (perbuatan) yang senang menolong orang lain, baik dalam bentuk material maupun dalam bentuk tenaga dan moril. Sikap ini sangat dipuji dalam Islam. Allah berfirnan:

${ }^{51}$ Turmudi, Juz IV, Op.Cit, h. 169. Hadis ini juga diriwayatkan oleh Bukhari, Kitab Jami' Shahih bab Tawhid: 2; Muslim, Kitab Jami' Shahih bab Fadhail: 66, dan; Ahmad bin Hanbal, Kitab Musnad jilid 3: 40. Lihat, A.J Wensink, jilid II, Op.Cit, h. 236

${ }^{52}$ Hamzah Ya'kub, Etika Islam, Bandung: Dipenegoro, 1991, h. 123-124

${ }^{53}$ Ibid., h. 125-127 


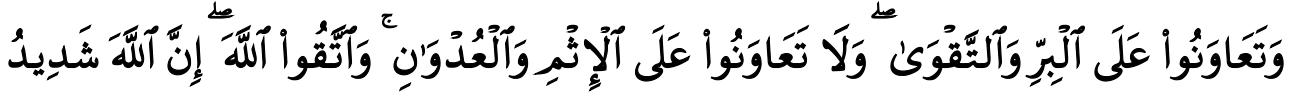

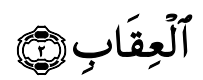

Artinya: "Dan tolong menolonglah kamu dalam (mengerjakan) kebajikan dan takwa, dan jangan tolong menolong dalam berbuat dosa dan pelanggaran. dan bertakwalah kamu kepada Allah, Sesungguhnya Allah Amat berat siksa-Nya. (Q.S al-Maidah/5:2)

Senada dengan ayat al-Qur'an di atas, Nabi SAW bersabda:

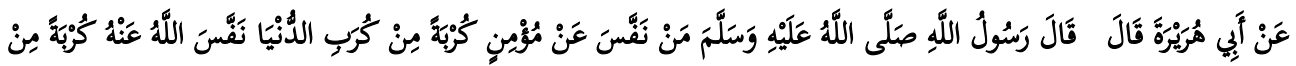

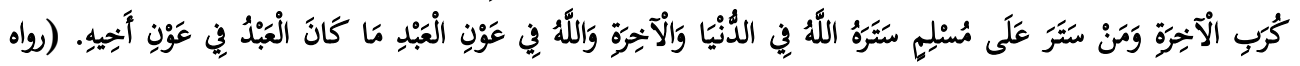

الترمذي)

Artinya: "Dari Abi Hurairah r.a, bersabda Rasulullah SAW "Siapa yang membebaskan kesusahan seorang yang beriman di dunia, maka Allah akan membebaskannya dari kesusahan di akhirat. Siapa yang menutup (aib) seseorang maka Allah akan menutup aibnya didunia dan akhirat. Allah akan selalu menolong seorang hamba, selama hamba itu menolong saudaranya." (H.R Turmudzi). ${ }^{54}$

Ketiga, pemaaf (al-'Afuw), yaitu sifat pemaaf yang tumbuh karena sadar bahwa manusia bersifat lemah (dha'if) tidak luput dari kesalahan dan kekhilafan. Dengan adanya sifat kasih sayang maka dia akan berlapang dada jika ada sahabatnya yang berbuat salah. Keempat, damai (al-ishlah). Orang yang jiwanya penuh kasih sayang akan memancarkan kedamaian dan perbaikan. Ia selalu cenderung mengulurkan tangan perdamaian kepada orang yang memusuhinya, dan tidak ingin mencari permusuhan dengan orang lain. Jika ada diantara orang yang bersengketa, sikapnya selalu cenderung untuk mendamaikan atau mencari perbaikan.

Demikianlah, uraian akan pentingnya sifat kasih sayang dan persaudaraan yang ternyata dapat ditemukan dalam tradisi megengan. Betapa tingginya nilai-nilai kearifan dan filosofis yang dirancang oleh para Wali Songo, sehingga nilai estetikanya agama Islam mampu dipakai oleh masyarakat kala itu hingga sekarang tanpa meruntuhkan nilai-nilai luhur yang dimiliki oleh masyarakat. Bahkan, Islam melalui para Wali di Nusantara hendak menyempurnakan nilai-nilai luhur yang sudah ada dan telah menjadi milik serta ciri kelompok etnik atau bangsa tertentu serta tidak bertujuan menghapus atau mencampakkannya dalam kehidupan sehari-hari, termasuk dalam tradisi megengan.

${ }^{54}$ Turmudzi, Juz III, Op. Cit, h. 115. Hadis ini juga diriwayatkan oleh Bukhri, Kitab Jami' Shahih bab Mazhalim: 3; Muslim, Kitab Jami' Shahih bab Birr: 59 dan al-Dzikr: 38; Abu Dawud, Kitab Sunan bab Adab: 38 dan 60; Ibn Majah, Kitab Sunan bab Muqaddimah: 17, dan; Ahmad bin Hambal, Kitab Musnad jilid II: 91, 252, 296. Lihat, A.J Wensink, jilid V, Op. Cit, h. 558 


\section{KESIMPULAN}

Tradisi Megengan merupakan suatu produk dari model pendekatan persuasif-cultural yang digunakan untuk menyemai agama Islam kepada penduduk bumi Nusantara (Jawa) pada masa lalu, dan hingga saat ini (modern) tradisi Megengan tetap dilaksanakan oleh masyarakat untuk menyambut datangnya Bulan Ramadhan. Tradisi Megengan bisa dipandang sebagai fenomena living Qur'an karena empat hal. Pertama, tujuan utama awal dari Tradisi Megengan adalah untuk meyiarkan ajaran Islam ke dalam masyarakat setelah masyarakat mulai mengenal Islam. Kedua, sebagai ungkapan rasa syukur kepada Allah Swt., sebagai atas diberikannya berbagai macam bentuk nikmat. Ketiga, bentuk daripada doa kepada para leluhur yang telah berpulang kehadirat Allah Azza wa Jalla. Keempat, wujud pemberian sedekah berupa makanan kepada tetangga. Kelima, meneguhkan Al-Akhwah dan Al-shilah alRahim (Persaudaraan dan Kasih Sayang)

\section{DAFTAR PUSTAKA}

A.J. Wensink, Mu'jam al-Mufahras lialfazh al-Hadits al-Nabawiy, Leiden, E.J Brill, 1936.

A.R. Idham, Cholid, Wali Songo: Eksistensi Dan Perannya Dalam Islamisasi dan Implikasinya Terhadap Munculnya Tradisi-Tradisi di Tanah Jawa, Jurnal Tamaddun, Vol 4, Edisi 1 Januari-Juni, Cirebon: IAIN Syekh Nurjati, 2016.

Aboebakar, Sejarah al-Qur'an, Jakarta: Sinar Pujangga, cet. III, 1952.

, Sejarah Hidup K.H.A Wahid Hasyim dan Karangan Tersiar, Jakarta: Panitia Buku, 1957.

Abu 'Abd Allah Ibn Muhammad ibn Yazid Ibn Majah, Sunan Ibn Majah, Lebanon, Beirut: Dar al-Fikr, 2004.

Abu 'Isa Muhammad bin 'Isa bin Saurah al-Turmudzi, Sunan al-Turmudzi, Beirut: Dar al-Fikr, 2005.

Abu al-Fida' Isma'il bin Katsir, Tafsir al-Qur`an al-Azhim, ttp: Syikah alNur Asia, th.

Abu Dawud Sulaiman bin al-Aya'ats al-Sijistaniy, Sunan Abu Dawud, ttp: Maktabah Dahlan, tth.

Abu Laits al-Samarqandi, Tanbih al-Ghafilin, ter. Oleh Abu Juhaidah, Jilid I, Jakarta: Pustaka Amani, 1999.

Achidsti, Sayfa Aulia, Strategi Penyebaran Tradisi Islam Pada Masyarakat Jawa, Jurnal Kebudayaan Islam, Vol. 10, No. 2, Juli-Desember, Yogyakarta: Universitas Gadjah Mada (UGM), 2012.

AG, Muhaimin, Islam Dalam Bingkai Budaya Lokal: Potret Dari Cirebon, terjemah oleh Suganda, Ciputat: Logos Wacana Ilmu, 2001. 
Ahimsa Putra, Heddy Shri, "Menafsir ,,al-Qur"an yang Hidup", Memaknai al- Qur"anisasi Kehidupan: Perspektif Antropologi Budaya", Makalah Seminar "Living Qur"an: Al-Qur"an sebagai Fenomena Sosial Budaya", Yogyakarta, 2005.

Ahmad bin Hanbal, Al-Musnad, Kairo: Dar al-Hadits, 1995.

Ali, Mukti, The Spread of Islam in Indonesia, Yogyakarta: Yasayasan "Nida", 1970.

Al-Nasa'i, Sunan al-Nasa'i, Lebanon, Beirut: Dar al-Fikr, 2005.

Al-Nawawiy, Shahih Muslim bi Syarh al-Nawawiy, Kairo: Dar al-Hadits, 2001.

Al-Thabrani, Mu'jam al-Ausath, dalam CD Maktabah al-Syamilah.

Al-Zabidi, Al-Tajrid al-Shahih li Ahadits Al-Jami' al-Shahih, terj. Ringkasan Shahih Al-Bukhari, Bandung: Mizan, 1999.

Arifin, Bey, Hidup Setelah Mati, Jakarta: Dunia Pustaka, 1984.

Arnold, Thomas, The Preaching of Islam: Lahore: Sh. Mohammad Ashraf, Kashmiri Bazar, cet. II, 1965.

Asy-Sya'rawi, Muhammad Mutawalli, Ishlahul Qulub, Depok: Keira Publishing, terj. oleh Mujahidin Muhayan, 2015.

Azra, Azyumardi, Jaringan Ulama Timur Tengah dan Kepulauan Nusantara Abad XVII dan XVIII, Bandung: Mizan, 1994.

Baihaqi, Sunan al-Kubra, dalam CD Maktabah al-Syamilah.

Berg, H. J. Van den. Dari Panggung Peristiwa Sejarah Dunia, Jilid I, terj. Koeskamp, I. P. Simandjoentak, Jakarta: J. B Walters, 1951.

Faris, Salman, Islam dan Budaya Lokal (Studi Atas Tradisi Keislaman Masyarakat Jawa), Jurnal Thaqafiyyat, Vol. 15, No. 1, Juni, Jakarta: STAI Az-Ziyadah, 2014.

Feillard, Andree, NU vis-a-vis Negara, Yogyakarta: LKiS, 1999.

Hakim, Muhammad Nur, Islam Tradisional dan Reformasi Pragmatisme (Agama Dalam Pemikiran Hasan Hanafi), Malang: Bayu Media Publishing, 2003.

Hamka, Sejarah Umat Islam, Jakarta: Nusantara, 1961.

Hamzah Ya'kub, Etika Islam, Bandung: Dipenegoro, 1991.

Ibnu Rajab al-Hanbali, Latha 'if al-Ma'arif.

Jakub, TK. Islamil, Sejarah Islam di Indonesia, Jakarta: Wijaya, t.th.

Johanes, Mardimin, Jangan Tangisi Tradisi, Yogyakarta: Kanisius, 1994.

Kaya, K. P., Dakkhin Bharate Muslim Missionai, terj. Abul Quasem Bhuiyan, Faridpur: Islamic Cultural Center, 1980. 
Khalil, Ahmad, Islam Jawa Sufisme Dalam Etika dan Tradisi Jawa, Malang: UIN Press, 2008.

Mahmud, Moh. Natsir, "Studi Al-Qur"an dengan Pendekatan Historisisme dan Fenomenologi Evaluasi Terhadap Pandangan Barat tentang AlQur"an" Disertasi, Yogyakarta: Program Pasca Sarjana IAIN Sunan Kalijaga Yogyakarta, 1992.

Malik bin Anas, Al-Muwthttha', Kairo: Dar al-Hadis, 1992.

Mansyur, Muhammad, Metodologi Penelitian Living Qur'an dan Hadis, Yogyakarta: TH. Press, 2007.

Martono, Nanang, Sosisologi Perubahan Sosial: Perspektif Klasik, Modern, Postmodern, dan Poskolonial, Jakarta: Rajagrafindo Persada, 2012.

Muhadjir, Noeng, Metodologi Penelitian Kualitatif, Yogyakarta: Rake Sarasin, 1996.

Muhammad bin 'Ismail al-Bukhariy, Jami' Shahih al-Bukhari, Beirut: Dar al-Fikri, 2006.

Mundziri, Logika, Jakarta: Raja Grafindo Persada, 1996.

Muntoha, Pemikiran dan Peradaban Islam, Yogyakarta: UII Press, cet. I, 1998.

Nainar, S. M. Husen, Islam di India dan Hubungan-hubungannya dengan Indonesia, Jakarta: Information Service of India, 1956.

Purwadi, Sejarah Sunan Kalijaga, Yogyakarta: Persada, 2003.

R. Soekmono, Pengantar Sejarah Kebudayaan Indonesia III, Yogyakarta: Yayasan Kanisius, 1973.

Shihab, M. Quraish, Menyingkap Tabir Ilahi: Asma al-Husna Dalam Perspektif Al-Qur'an, Jakarta: Lentera Hati, 1999.

, Tafsir al-Misbah, Jakarta: Lintera hati, 2006.

Soekanto, Soerjono, Pengantar Penelitian Hukum, Jakarta: UI Press, 1986.

Syaikh al-Arif al-Sya'rawi, Faidh al-Qadir, Juz III.

Syamsuddin, Sahiron, "Ranah-ranah dalam Penelitian Al-Qur'an dan Hadis”, Kata Pengantar, dalam Metodologi Penelitian Living Qur'an dan Hadis, Yogyakarta: Teras, 2007.

Syamsul Arifin dkk., Syamsul, Spiritualisasi dan Peradaban Masa Depan, Yogyakarta: SIPRESS, 1996.

Syed Muhammad Husein Al-Thabatha i, Tafsir al-Mizan, jilid VIII, Beirut: Muassasah al-'Alami li Mathbu'at, 1991. 